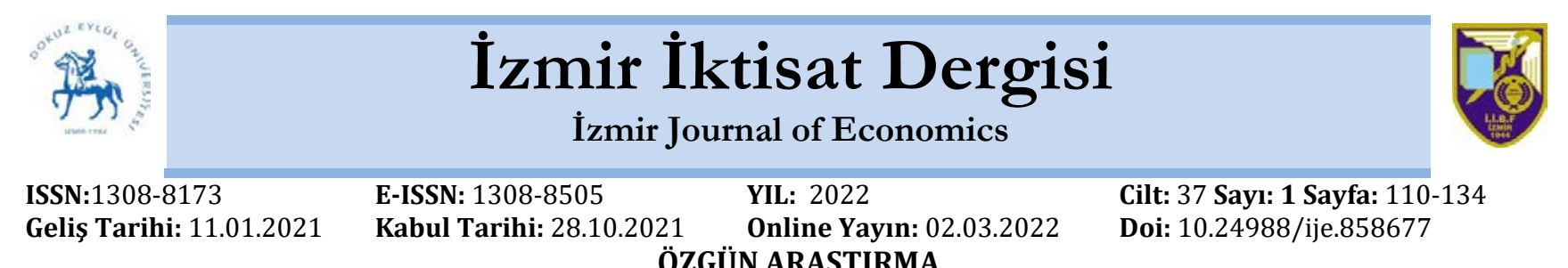

ÖZGÜN ARAŞTIRMA

\title{
Örgüt İçi Rekabetin Örgütsel Kıskançlığa Etkisinde Öz Saygının Rolü: Sivil Havacılık Çalışanları Üzerine Bir Araştırma

\author{
Berat ÇIÇEK ${ }^{1}$, İnan KAYNAK ${ }^{2}$
}

\begin{abstract}
Özet
İs dünyasında rekabet her ne kadar istenen ve olumlu bir durum gibi görünse de organizasyon içerisindeki bireyleri bazı istenmeyen davranışlara sevk edebileceği göz ardı edilebilmektedir. Bu düşünceden hareketle, bu çalışmada örgüt içi rekabetin örgütsel kıskançllk üzerindeki etkisinin ortaya konulması ve bu iki değişken arasındaki ilişkide öz saygının rolünün tespit edilmesi amaçlanmıştır. Bu amaç doğrultusunda oluşturulan hipotezleri test etmek için nicel araştırma yönteminden yararlanılmıştır. Bu bağlamda sivil havayolu taşımacılığı çalışanı 256 kişi ile bir anket çalışması gerçekleştirilmiştir. Elde edilen veriler, yapısal eșitlik modellemesi yaklaşımına göre test edilmiştir. Analizler sonucunda elde edilen bulgulara göre, örgüt içi rekabetin başkalarını kıskanmayı ve kıskanıldığını düşünmeyi artırdığı, öz saygıyı ise azalttığı görülmüştür. Öz saygının ise kıskançlığı azalttığı, ayrıca örgüt içi rekabet ile kıskançlık ilişsisine de aracılık ettiğgi sonucuna ulaşılmıştır. Araştırma, rekabetin olumsuz yönüne odaklanması, rekabet, kıskançlık ve öz saygı değişkenlerini bir arada ele alması yönleriyle özgün bir çalışmadır.
\end{abstract}

Anahtar Kelimeler: Örgüt İçi Rekabet, Örgütsel Kıskançlık, Öz Saygı

JEL Kodu: M10, M12, C12

\section{The Role of Self-Esteem in the Effect of Intra-Organizational Competition on Organizational Jealousy: A Study on Civil Aviation Employees}

\begin{abstract}
Although competition in the business world seems to be a desirable and positive situation, it can be overlooked that it can lead individuals within the organization to some undesirable behaviors. With this in mind, this study aims to reveal the effect of intra-organizational competition on organizational jealousy and to determine the role of self-esteem in the relationship between these two variables. Quantitative research method was used to test the hypotheses created for this purpose. In this context, a survey was conducted with civil aviation employees. The data obtained were tested according to the structural equation modeling approach. According to the findings of the study, it has been observed that intraorganizational competition increases the envy of others and the thinking that they are envious, and decreases the selfesteem. It has been concluded that self-esteem reduces envy and also mediates the relationship between competition and jealousy within the organization. The research is an original study in that it focuses on the negative side of competition, and handles the variables of competition, and self-esteem together.
\end{abstract}

Keywords: Intra-Organizational Competition, Organizational Envy, Self-Esteem

JEL Classification: M10, M12, C12

ATIF ÖNERİsi (APA): Çiçek B., Kaynak İ., (2021). Örgüt İçi Rekabetin Örgütsel Kıskançlığa Etkisinde Öz Saygının Rolü: Sivil Havacılık Çalışanları Üzerine Bir Araştırma. İzmir İktisat Dergisi. 37(1). 110-134. Doi: 10.24988/ije.858677

1 Doç. Dr., Malatya Turgut Özal Üniversitesi Sivil Havacıllk Yüksekokulu, Battalgazi/MALATYA EMAIL: berat.cicek@ozal.edu.tr ORCID: 0000-0002-4584-5862

2 Dr. Öğr. Üyesi, Muş Alparslan Üniversitesi Malazgirt Meslek Yüksekokulu, Malazgirt/MUŞ, EMAIL: i.kaynak@alparslan.edu.tr ORCID: 0000-0001-9944-1540 


\section{GíRiş}

İnsan yaşamı boyunca iyi veya kötü, olumlu veya olumsuz birçok duyguyla var olan bir canlıdır (Taştan ve Aydın Küçük, 2019). Bireylerin duyguları ise örgüt yaşamının ayrılmaz bir parçasıdır (Ashforth ve Humphrey, 1995). Bu sebeple sosyologlar ve örgütsel teorisyenler uzun zamandan beri bireylerin davranış ve inançlarının örgütlere olan etkisini araştırmaktadırlar (Sorensen, 1999). Bireyler istek ve ihtiyaçlarını karşılamak için bulundukları örgütlerde (Dinçer, 2013) kaynakların sınırlı oluşu ve bazı motivasyon araçlarının etkisi gibi nedenlerle birbirleriyle veya gruplar arasında rekabet ortamının oluşmasını sağlarlar (Khon, 1992). Örgüt performansında olumlu çıtılarından dolayı (Luft, 2016) örgütsel gelişmede önemli bir yeri olan (Ingram ve Qingyuan Yue, 2008) ve değeri giderek artan örgüt içi rekabet kavramı (Becker-Ritterspach ve Dörrenbächer, 2011); tanınma, maddi veya manevi ödüllerin kazanımına ilișkin çalışanların bireyler veya gruplar arası üstünlük sağlama çabası olarak nitelendirilmektedir (Fletcher ve Nusbaum, 2010). Rekabetçi avantajın birincil kaynağı olan çalışanlar (Keçecioğlu ve Yılmaz, 2018) örgüt içinde veya dışında birbirleriyle ve birbirlerine karşı (Swab ve Johnson, 2019) en iyiyi yapma gayreti şeklinde davranışlar sergilerler (Deutsch, 1986). Rekabetçi davranışların genel olarak savunmaya ve saldırıya dönük oluşu (Coulter, 2013) beraberinde örgütsel açıdan bazı belirsizlikler doğurabilmektedir (Seçkin, 2020). Örgüt içi rekabette birinin kazanımının diğerinin zararına olması (Landkammer ve Sassenberg, 2016), çalışanları öfkelendirebilmekte (Le Fevre, Matheny ve Kolt, 2003) ve aşırı rekabet duygusu çalıșanlar arasında kıskançlık benzeri duygulara neden olabilmektedir (Durmuş, 2021; Özdemir, 2018; Üçok, 2019).

Psikolojik araştırmalara konu olan ve olumsuz bir duygu olarak nitelendirilen (Pines ve Aronson, 1983), anlaşılması ve tanımlanması zor bir kavram olan kıskançlık (Daher ve Cohen, 1979); bir kişinin başkasında kendisinden üstün özellikleri fark etmesi (Parrott ve Smith, 1993) ve bu durumu ele geçirme isteği olarak tanımlanmaktadır (Salovey ve Rodin, 1988). İnsan davranışlarını etkileyebilen duygulardan biri olan kıskançlı̆̆ın (Günalan, 2019) örgütlerde yaşanılması kaçınılmazdır (Dogan ve Vecchio, 2001). Örgütlerde yaşanılan kıskançlık çalışanlar ve örgütler üzerinde (Kıral ve Ödemiş Keleș, 2019) yıkıcı güçlere sahip sonuçlar doğurabilmekte (CohenCharash ve Mueller, 2007) ve çalışma ortamında ki bu negatif durum çalışanların öz saygılarını etkileyebilmektedir (Jacob ve Neuhäuser, 2018).

Öz saygı, bir kişinin kendi değer duygusunu, güvenini inancını içerir (Mckinnon, 2003) ve kendini diğerlerinden daha iyi görmemekle birlikte kesinlikle daha kötü görmemesi olarak ifade edilmektedir (Neff, 2003). Çoğu insan özsaygıyı önemli (Baumeister, Campbell, Krueger ve Vohs, 2003) ve araştırmaya değer bir kavram olarak görmektedir (Massey, 1983). Yüksek öz saygısı olan çalışanların diğer çalışanlarla ilişkisi daha sağlıklı olur ve bu ilişski şekli örgüt içinde çalışanlar arasında örnek teşkil edebilir (Kumashiro, Finkel ve Rusbult, 2002). Bireylerin öz saygılarını geliştirmek, sürdürmek ve yeniden inşa etmek örgüt performansı açısından önem arz etmektedir (Kampen, Elshout ve Tonkens, 2013).

Yöneticilerin örgüt performansını yükseltmek için başvurabildikleri ve çalışma hayatının bir gerçeği olan bireyler ya da gruplar arası rekabetin örgüt veya çalışanları nasıl etkilediğine yönelik yürütülen araştırmalar görece azdır (Johnson ve Swab, 2018). Bu çalışmalardan bazıları rekabetçi çalışma ortamının çalışanların bireysel veya grup olarak rekabetçi davranmalarını sağladığını (Fletcher ve Nusbaum, 2010) ve örgüt performansını arttırdığını (Brown, Cron ve Slocum, 1998) ayrıca iş performansı ile iş tatmini arasındaki ilişkinin güçlendiği sonucuna varmışlardır (Arnold, Flaherty, Voss ve Mowen, 2009). Çalışma ortamlarında kabul edilmiş varoluşlarına rağmen, çalışan kıskançlığı da örgütsel bilimler içinde ihmal edilmiş konulardandır (Vecchio, 2000). Bu çalışmalardan bazılarının sonuçlarına göre kıskançlık; grup performansı ve grup uyumu üzerine olumsuz etki 
ederek sosyal kaytarmaya (Duffy ve Shaw, 2000), işten çekilme veya işletmeden ayrılmaya (Dogan ve Vecchio, 2001), daha az işbirlikçi davranışa (Parks, Rumble ve Posey, 2002) ve çalışanların daha az çaba harcamaları sonucunda firmanın değerinin azalmasına neden olmaktadır (Goukasian ve Wan, 2010). Öz saygıyı konu alan çalışma sonuçlarına göre de öz saygı; çalışanların iş yeri memnuniyetini (Pierce, Gardner, Dunham ve Cummings, 1993), örgütsel bağlılığını (Güney, Akalın ve İlsev, 2007) ve iş performansını arttırdığı tespit edilmiştir (Yücel ve Solak, 2012). Rekabet ve kıskançlık kavramlarının beraber ele alındığı çalışma sonuçlarında ise örgüt içi rekabet ortamının kıskançlık benzeri duygular yaratabileceği (Dogan ve Vecchio, 2001), kontrol altına alınamayan kıskançlığın ise yıkıcı rekabeti beraberinde getirdiği sonucuna varılmıştır (Eginli ve Bitirim, 2010).

Birçok insanın kendini değerli hissettiği bir yer olan çalışma ortamında (Baderin ve Barnes, 2018) yaşanılan rekabet ve kıskançlık davranışları örgütsel açıdan olumlu ve olumsuz sonuçlar doğurabilen kavramlardır. Fakat örgüt içi rekabet ve kıskançlık kavramlarının birbiri ile olan etkileşimini inceleyen araştırmaların sayısı sınırlıdır. Ayrıca örgüt içi rekabet, örgütsel kıskançlık ve öz saygı kavramlarını bir arada ele alan çalışmaya rastlanılmamıştır. Tüm bu sebeplerle özgün olduğu düşünülen bu çalışmanın yazına katkı sunacağı öngörülmektedir.

\section{KAVRAMSAL ÇERÇEVE}

Rekabet doğası gereği kişilerin kendilerini diğer bireylerin yetenek ve performansıyla kıyasladığı bir tür karşılaştırma faaliyetidir (Garcia vd., 2013). Bu kıyaslama çabasının açıklanmasıyla ilgili ilk kuram Festinger (1954) tarafından ortaya atılan sosyal karşılaştırma kuramıdır. Bu kurama göre, bütün bireylerde fikir ve yeteneklerini değerlendirebilmek adına evrensel bir dürtü bulunmaktadır. Değerlendirilmek arzusunda olan bireyler öncelikli olarak objektif bir ölçüt arayışına girerler. Bu ölçütün her zaman olması mümkün olmadığından diğer bireylerle karşılaştırma yaparak kendilerini değerlendirebilecekleri bilgiye ulaşırlar (Festinger, 1954). Van Houten (1979) ise sosyal karşılaştırmayı çalışma ortamında bir kişinin performansını diğer kişilerile karşılaştırması olarak açıklamıştır. Bu kıyaslama kişinin rekabetçi davranış sergilemesini sağlayabilmektedir (Johnson, 2012). Taylor vd. (2007) 'ne göre, sosyal karşılaştırmada referans alınan kişilerin rakiplere dönüşmesi başlangıçta kişinin güven duygusunu ve motivasyonunu arttırırken bazen de kişinin kendini başarısız ve yetersiz hissetmesine neden olabilmektedir. Bu durum karşılaştırma yapan veya yapılan kişilerde olumsuz davranışların doğmasına sebep olabilmektedir (Poortvliet, 2013). Bu noktada önemli olan kişinin kendini kimlerle karşılaştırdığı sorusudur. Çünkü karşılaştırma sonucunda kişi kendiyle ilgili olumlu veya olumsuz bilgiye erişebilmektedir (Collins, 2000). Sosyal karşılaştırmalar genelde kendiliğinden gerçekleşse de stresli ve zor ortamlarda artış göstermektedir (Gibbons ve Buunk, 1999). Bu ortamlardan biri de rekabetin yoğun yaşandığı örgüt ortamlarıdır. Bu ortamda karşılaștırmaya taraf olan bireyler motivasyon kaynağı olabildiği gibi aşağılık ve kıskançlık gibi hislerinde kaynağı olabilmektedir (Vecchio, 2000).

\section{1. Örgüt içi rekabet}

Örgütler bireylerden, çalışma ekiplerinden, gruplardan ve bölümlerden oluşan karmaşık ve hiyerarşik birliklerdir (Swab ve Johnson, 2019) ve çalışan ilişkileri bu ortamda işe dayalı olarak ortaya çlkmaktadır (Demirel ve Karadal, 2007). Bu ilişkilerde bireyleri bencil davranmaya itebilecek birçok etken olmasına rağmen bireylerden örgütün başarısı için iş birliği içinde davranması beklenmektedir (Goette, Huffman, Meier ve Sutter, 2012). Fakat çalışanların özellikleri, tutumları, inançları, tercihleri, davranışları, bireylerle ve gruplarla ilişkileri (Krueger, 2000), çıkarları ve statü algılamaları (Kapıcı ve Radmard, 2019) bireyler veya ekipler arasında rekabeti ortaya çlkarabilmektedir (Khon, 1992).

Rekabet, bir amaca dönük olarak, birinin amaca ulaşmasının diğerinin şansını azalttığı ya da engellediği en az iki aktörün çabası olarak tanımlanmaktadır (Eren, 2003). Rekabet sadece bireyleri 
değil aynı zamanda örgütleri de etkilemektedir (Ingram ve Qingyuan Yue, 2008). Kişilerarası rekabette başarı bir kişinin başka bir kişi veya kişilere göre ulaştığı üstünlük iken (Elliot, Jury ve Murayama, 2018) örgüt içi rekabet; bir veya daha fazla bireyin aynı amaç için motive edilen aynı örgütteki başka bir birey veya grupla bir hedefe ulaşmaya yönelik olarak yaptığı iş ve işlemelerin bütünü olarak tanımlamaktadır (Salvador ve Costa, 2009). Bu tanımlardan hareketle kişisel rekabette başarı kişinin başarısı veya başarısızlığı olurken örgüt içi rekabette başarı hem birey hem de örgütün başarısı veya başarısızlığı olabilmektedir.

Örgütlere olan katkılarından dolayı rekabet (Khon, 1992), çalışanlar arasında serbest bırakılmakta ve hatta teşvik edilmektedir (Becker-Ritterspach ve Dörrenbächer, 2011). Çünkü, tembelliği engelleyip çalışanların verimini artırarak sürekli kılmaktadır (Stepan-Norris ve Southworth, 2010). Ayrıca örgüt içinde yenilik ve üretkenliğin ana kaynağı olarak (Yeşilada ve Yeniçeri, 2020), eşgüdümü temin etmektedir (Eren, 2003). Rekabet örgüte bazı firsatlar sunmakla beraber (Ingram ve Qingyuan Yue, 2008), örgütü olumsuz olarak da etkileyebilmektedir (Erdoğmuş, 1999). Organizasyonlarda rekabet çalışanların duygu dünyasını (Wittchen, Krimmel, Kohler ve Hertel, 2013) performansını (Beersma ve diğerleri, 2003) motivasyonunu, sağlı̆̆ını, ve psikolojik iyi oluşunu olumsuz etkileyebilmektedir (Van De Voorde ve diğerleri, 2012). Bununla birlikte kariyerinin başında olup gelişmek isteyen çalışanlarda öfkeye sebep olabilmektedir (Le Fevre ve diğerleri, 2003). Tüm bu sonuçlarının neticesinde örgüt içi rekabet, çalışanların ilişki kalitesini düşürebilmekte, kaygı düzeylerini, saldırganlık davranışlarını arttırabilmekte ve "kıskançlık" benzeri etik olmayan davranışlar göstermelerine sebep olabilmektedir (Khon, 1992).

\section{2. Örgüt İçi Rekabet ile Kıskançlık İlişskisi}

Bireyler sosyalleşme sürecinde sağlıklı ilişkiler kurabildikleri gibi ilişkilerin kurulmasını engelleyen bazı davranışlar da gösterebilmektedirler. Bu davranışlardan biri de kıskançlık davranışıdır (Malkoç ve Erginsoy, 2012). Çoğu zaman anlaşılması zor bir kavram (Daher ve Cohen, 1979) ve çağdaş toplumlarda büyük sosyal sorunlara neden olan (Smith, 2008) kıskançlık, genelde olgunlaşmamış bir duygu, güvensizlik belirtisi veya ruhsal bir bozukluk olarak kabul edilmektedir (Özer, 2002).

Kıskançlıkla ilgili birçok tanımlama yapılmış olmakla birlikte genel olarak kıskançlık; bireylerin gerçek veya hayali bir rakibinin (DeSteno ve Salovey, 1996) özelliklerini kendi özellikleri ile karşılaştırma süreciyle ortaya çıkan (Buunk ve Dijkstra, 2015), acı verici (Van de Ven, Paauwe ve Van Veldhoven, 2009) ve kaybetme korkusu gibi duygular barındıran (Tai ve diğerleri, 2012), sosyal ilişkinin varlığına veya kalitesine yönelik tehditler içeren (Guerrero, Andersen, Jorgensen, Spitzberg ve Eloy, 1995), neredeyse tüm sosyal ilişkilerde bulunan (Andiappan ve Dufour, 2020), hissetme eğilimi yaygın ve tüm kültürlerde mevcut (Foster, 1972), kendini rakibinin seviyesine taşıyarak veya rakibini kendi konumuna çekmesiyle azalan veya ortadan kalkan (Van de Ven ve diğerleri, 2009) sosyal bir duygu olarak tanımlanabilir (Kıral, 2018).

İş yerindeki ilişkiler, birey ve örgütler için önemlidir (Balkundi ve Harrison, 2006). İşyerleri duygudan arınmış ortamlar değildir (Goukasian ve Wan, 2010). Aksine iş yerleri duyguların yoğun olarak yaşandığı alanlardır (Andiappan ve Dufour, 2020). Bu sebeple çalışma ortamlarındaki duygu durumları farklılık arz eder (Bayram Arlı, Aydemir ve Çelik, 2018). İnsani bir duygu olan kıskançlık (Günalan, 2019), işyerlerinde çok yaygın olarak görülmektedir (Tai, Narayanan ve Mcallister, 2012). Çalışanların kendilerine olan saygılarını kaybetmeleri anlamına gelen (Vecchio, 2000) ve toksik bir davranış olarak kabul edilen çalışan kıskançlığı (Töremen ve Çankaya, 2008), güçlü bir duygudur ve örgütlerde var olması bazı olumsuz durumlara sebep olabilir (Salovey ve Rodin, 1988).

Kendi konumunu iyileștirmeyi amaçlayıp (Van de Ven ve diğerleri, 2009) rakibine zarar verme düşüncesi olan (Cohen-Charash ve Mueller, 2007) çalışan kıskançlığı, davranışsal yanlıș yorumlamalara yol açarak yıkıcı davranışlara sebep olabilmektedir (Guerrero ve diğerleri, 1995). 
Rakibini aşağılama gibi (Crusius ve Lange, 2014) etik olmayan davranışlarda bulunarak (Gino ve Pierce, 2009), performans ve çalışan refahının azalması (Zurriaga ve diğerleri, 2018), işe devam ve başkalarına görevlerinde yardımcı olma gibi genel örgütsel vatandaşlık davranışlarında azalma (Wang ve Sung, 2016) ve rakipleriyle bilgi paylaşımından kaçınma (Dunn ve Schweitzer, 2004) gibi nedenlerle iş kalitesinin düşüșe neden olabilir (Dogan ve Vecchio, 2001). Kıskançlık sosyal kaytarma, hedef gerçekleştirme ile birlikte gruptan ayrılma ve odak aktörün maruz kaldığı adaletsizlik duygusu nedeniyle grup performansı ve bağlılığını (Lange ve Crusius, 2015) ayrıca kişinin terfi şansı ve organizasyonel entegrasyonunu olumsuz etkilemekte (Balkundi ve Harrison, 2006), kendini üstün görme ve diğer kişileri cezalandırma veya taciz eğilimini güçlendirme sebeplerinden dolayı kışkırtıcı olabilmektedir (Özen, 2007). Kıskançlık davranışı bireyler üzerinde baskı kurma niyeti ve ihtiyacından dolayı şiddetle bile sonuçlanabilmektedir (Aba ve Kulakaç, 2016).

Kıskançlık bireyler ve örgütler için olumsuz sonuçlara sebep olduğu gibi olumlu sonuçlarında doğmasını sağlayabilir (Kıral ve Ödemiş Keleş, 2019). Kıskanç birey rakibe zarar verme ve rakibi alt etmek suretiyle (Crusius ve Lange, 2014) rakibine karşı küçümseme ile sonuçlanan bir sosyal karşılaştırma yapar (Melwani ve Barsade, 2011). Bu durum rakibin iş performansını (Tai ve diğerleri, 2012), iş motivasyonunu ve öz saygısının artmasını sağlar (Van de Ven ve diğerleri, 2009). İşyerinde tatlı rekabete dayalı bir kıskançlık çalışanların performansının artmasını ve örgütün bundan olumlu yönde istifade etmesini sağlayabilir (Tarhan, 2018).

Örgüt içi rekabet ve kıskançlık konularını ele alan çalışmaların sonuçları genel olarak değerlendirildiğinde; örgüt içi rekabetin hedef, performans (Elliot ve diğerleri, 2018), iş tatmini, üzerinde olumlu etkisinin olduğu (Arnold ve diğerleri, 2009), rekabetin olmadığ durumlarda ise verimsizlik ve zarar benzeri istenmeyen sonuçlarla karşılaşıldığı görülmektedir (Barmby, Sessions ve Zangelidis, 2016). Kıskançlıkla ilgili çalışmalara bakıldığında ise kıskançlığın tükenmişliğe (Geurts, Schaufeli ve De Jonge, 1998), performans kaybına ve verimsizliğe neden olduğu (Kıral ve Ödemiş Keleş, 2019) ayrıca örgüt içi rekabetçi ortamın çalışan kıskançlığına sebep olan faktörlerden (Dogan ve Vecchio, 2001) biri olabileceği sonucuna varmışlardır. Tüm bu sonuçlardan hareketle aşağıdaki hipotez geliştirilmiştir.

H1a: Örgüt içi rekabet kıskanıldığını düşünmeyi pozitifyönde etkiler.

H1b: Örgüt içi rekabet başkalarını kıskanmayı pozitif yönde etkiler.

\section{3. Öz Saygı}

Öz saygı, insan davranışı ve kişiler arası etkileşimi açıklamada etkili olan temel psikolojik faktörlerden biridir (Clark ve Goldsmith, 2005). Öz saygl, kișinin kendini sevmesi, kabul etmesi ve kendine saygı duyması gibi öz değerlendirmelerinden oluşan (Truong ve McColl, 2011) kendine karşı sahip olduğu öznel bir tutumdur (Statman, 2000). Öz saygı genellikle bir kişinin statüsüne ilişkin algısı açısından tanımlanmakla beraber (Mckinnon, 2003), farklı bakış açılarından kaynaklanan farklı tanımlar da vardır (Crocker ve Major, 1989).

Bu tanımlardan bazıları şunlardır: Öz saygı; kendinizle gurur duyma ve kim olduğunuzdan emin olma (Gurel Atay, Xie, Chen ve Kahle, 2010), kendini takdir etme (Dillon, 2019), hakları ve saygınlığ açısından kendilerini başkalarına eşit görme becerisi (Renger, 2017), kendisiyle ilgili güçlü fikirleri olan bireylerin kendilerine karşı bir tür iyiliği (Telfer, 2010) ve bireyin kendine saygı duyması, kendini değerli görmesi, kendini diğerlerinden daha iyi görmemekle birlikte kesinlikle daha kötü görmemesidir (Neff, 2003).

Öz saygl, bilişsel, duyuşsal ve davranışsal boyutlar içerir (Smith, 2000) ve teorisyenler arasında öz saygının bir tutum olduğu konusunda fikir birliği vardır (Roland ve Foxx, 2003). Fakat öz saygının nasıl kavramsallaştırılacağına dair ortak bir düşünce olmamasına rağmen (Dillon, 2019) öz saygl, iki 
şekilde tanımlanmaktadır. Bunlar "değer biçme saygısı" ve "tanıma saygısı" şeklindedir (Doppelt, 2009). Değer biçme saygısı kişinin kendini olumlu değerlendirmesini ifade eder ve kişinin karakterinin mükemmelliğine dayanır (Roland ve Foxx, 2003). Tanıma saygısı ise kişinin sahip olduğu kapasitesini tanınması ve uygun davranması olarak nitelendirilir (Dillon, 2019). Tanıma saygısı, bireyi uygun davranışlarda bulunmaya ve değersiz davranışlardan kaçınmaya motive eder (Roland ve Foxx, 2003).

Öz saygl, literatürde farklı şekillerde ele alınmıştır (Güney ve diğerleri, 2007). Bunlara örnek olarak "evrensel öz saygı", "role özgü öz saygı" ve "göreve veya duruma özgü öz saygı" sayılabilir (Pierce ve Gardner, 2004). Simpson ve Boyle (1975) evrensel öz saygıyı role özgü öz saygı ve duruma özgü öz saygının toplam değerlendirmesi olarak açıklamıştır. Kumashiro vd. (2002) ise ahlaki standartlar ile onur ve ilkeli davranışların evrenselliği ile açıklamıştır. Güney vd. (2007) ise farklı güçlerden etkilenen kendisi ve sosyal çevresinden aldıkları ve kişisel tecrübeleri neticesinde oluşturduğu yeterlilik duygusu olarak özetlemiştir. Role özgü öz saygı yaşam süresince sergilenen anne-baba, eş, öğrenci ve benzeri rollerin öz değerlendirmesidir. Göreve veya duruma özgü öz saygı ise, belirli bir durumlarda sergilenen davranışların sonuçları ve bireyin ifa ettiği görevdeki yeterliliğinin öz değerlendirmesi olarak açıklanmıştır (Pierce ve Gardner, 2004). Öz saygı evrensel, role özgü ve göreve özgü öz saygı olarak ayrılmıştır. Daha sonra iş görenlerin örgüt içindeki önemi, etkisi ve değerini açıklamaya çalışan örgüt-temelli öz saygı kavramı geliştirilmiştir (Güney ve diğerleri, 2007). Örgüt-temelli öz saygı ise örgüt üyelerinin, örgüt içinde roller alarak ihtiyaçlarının karşılanabildiğine olan inanma dereceleri (Korman, 1966) veya örgütün bir üyesi olarak yetenekli ve değerli oluşuna inanç derecesi olarak tanımlanmıştır (Pierce ve diğerleri, 1993).

İşyeri, çalışanlar için birçok açıdan önemli ortamlardır (Baderin ve Barnes, 2018). Bu sebeple öz saygı örgütlerde çalışan yeteneğinin göstergesi olabilirken (Pierce ve diğerleri, 1993) işyerlerinin örgütlenme şekli de çalışanların öz saygılarını etkileyebilmektedir (Jacob ve Neuhäuser, 2018). Bu bağlamda öz saygının çalışanlar ve örgütler üzerinde bazı zararları veya faydaları olabilmektedir (Kumashiro ve diğerleri, 2002). Bireyler öz saygıları üzerinde önemli ölçüde kontrol ve sorumluluk sahibidirler (Doppelt, 2009) ve öz sayglarını artırmak için çabalarlar (Truong ve McColl, 2011). Yüksek öz saygısı olan bireyler kendilerine başarılması zor çok yüksek hedefler koyma eğilimindedirler ve bu hedeflerde başarısızlığa, öfke veya şiddete neden olabilmektedir (Baumeister, Smart ve Boden, 1996). Öz saygl, bireyin kendine inanıp inanmadığının ifadesidir (Renger ve diğerleri, 2019). Öz saygının yitirilmesi ise bu inancın kaybı demektir (Telfer, 2010). Bu durum düşük öz saygıya (Isaksen ve Roper, 2016) düşük öz saygı ise özgüven kaybına neden olmakta (Sachs, 1981) ve neticede bu bireyler diğer kişilerin etkisi altında kalmaya daha müsait duruma gelmektedirler (Silvera ve diğerleri, 2008). Öz saygısından zevk alan kişiler bu durumda olanlara karşı saygısızlık ve küçümseme davranışı gösterebilmektedirler (Sachs, 1981). Çalışan kişiler veya grupların düzenli olarak saygısızlık ve aşağılanmaya maruz kalması durumunda bu kişi veya gruplar öz saygılarını yeniden kazanılmasında çok az umut sahibi olabilmektedirler (Telfer, 2010). Ayrıca iş güvensizliği (Baderin ve Barnes, 2018), rekabetçi olmayan teşvikler (Penny, 2013) ve daha az değerli ve tatmin olmuş hissetmek öz saygının azalmasına ve bu sonuçlarda örgütlerde istenmeyen sonuçlara neden olabilmektedir (Pierce ve Gardner, 2004). Buradan hareketle araştırmada test edilmek üzere aşağıdaki hipotez kurulmuştur.

\section{H2: Örgüt içi rekabet öz saygıyı negatif yönde etkiler}

Öz saygı önemli ve değerlidir (Baumeister ve diğerleri, 2003) ve değerli olduğu için bireyin değerine katkıda bulunur (Boxill, 1976). Mesleki başarı öz saygıyı artırabilir (Baumeister ve diğerleri, 2003). Öz saygısı artan bireyin kendine olan güveni ve inancı artar (Dillon, 1997). Böylece öz saygı, büyük bir amaç duygusunun oluşumunu sağlar (Roland ve Foxx, 2003). Yüksek öz saygısı olan çalışanların diğer çalışanlarla ilişkisi daha sağlıklı olur (Kumashiro ve diğerleri, 2002). Bireylerin öz saygılarını 
geliștirmek, sürdürmek ve yeniden inşa etmek örgüt kaynakları açısından önemlidir (Kampen ve diğerleri, 2013) ve öz saygılarını desteklemek için bir araç olarak kullanılabilir (Penny, 2013). Öz saygı, bireyin performansı ile yakın ilişkilidir. Bireysel performans ise örgütün hedeflerine ulaşmasını etkileyecektir. Bu nedenle öz saygı örgütler açısından önemli bir değişkendir. Zira yüksek öz saygı örgütleri hedeflerine yaklaştırırken düşük öz saygı bu hedeflerden uzaklaşılmasına neden olabilir (Yüner, 2018). Öz saygının mesleki memnuniyeti ve başarıyı arttırıp (Erez ve Judge, 2001), kıskanma davranışını azaltabileceği varsayımından yola çıkarak aşağıdaki hipotezler kurulmuştur.

Hз: Öz saygı kıskanıldı̆̆ını düşünmeyi negatif yönde etkiler

\section{Hзb: Öz saygı başkasını kıskanmayı negatifyönde etkiler}

Öz saygı ile ilgili araştırma sonuçlarına genel olarak bakıldığında çalışanların öz saygılarının artması çalışan performansını (Yücel ve Solak, 2012), iş yeri memnuniyetini (Pierce ve diğerleri, 1993) ve örgütsel bağlılığı arttırıcı (Güney ve diğerleri, 2007), öz saygının azalması ise mesleki hazzın azalması (Karaçam, Pulur ve Adigüzel, 2017) ve kendini engelleme gibi bazı davranışların artması sonucunu doğurduğu tespit edilmiştir (Yıldırım ve Demir, 2017). Ayrıca mesleki tecrübe azlığı öz saygının azalması ve karar verme davranışlarında ise çekingenliğe sebep olduğu (Certel, Bahadır ve Sönmez, 2013) diğer bazı sonuçlardır. Bu sonuçlardan hareketle oluşturulan hipotezler şu şekildedir:

$H_{4 a:}$ Öz saygı örgüt içi rekabet ile kıskanıldığını düşünme arasındaki ilişkiye aracılık eder.

$H_{4 b:}$ Öz saygı örgüt içi rekabet ile başkasını kıskanma arasındaki ilişkiye aracılık eder.

\section{YÖNTEM}

Çalışmanın temel amacı örgüt içi rekabetin çalışan kıskançlığı üzerindeki etkisini ve bu iki değişken arasındaki ilişkide özsaygının rolünü ortaya koymaktır. Değişkenler arasındaki ilişkinin durumunu tespit etmek için nicel araştırma yönteminden yararlanılmıştır. Anket yöntemi ile elde edilen verilerin analizinde Yapısal Eşitlik Modellemesi (YEM) benimsenmiştir. YEM yaklaşımının tercih edilmesinin temel sebebi YEM'in teorik ve ampirik çalışmaların istatistiki olarak daha gelișmiş bir zeminde yapılmasına olanak sunması ve YEM yaklaşımlarının tutarlı bir şekilde bir aracılık rolü sonucunu tespit etmede, regresyon yaklaşımından daha güçlü olmasıdır (Iacobucci, Saldanha ve Deng, 2007). Araştırmada test edilmek üzere kurulan model Şekil 1'deki gibidir.

Araştırmada kurulan model Anderson ve Gerbing (1988) tarafından önerilen, verileri ve hipotezleri test etme adımlarından oluşan iki aşamalı yaklaşıma göre analiz edilmiştir. Bu bağlamda öncelikle uyuşum ve ayırt edici geçerliliği test etmek için ölçüm modeli kurulmuştur. Daha sonra hipotezleri test etmek için yapısal model kurulmuştur. Kurulan modelleri test etmek için Mplus 8.4 (Muthén ve Muthén, 2017) programından yararlanılmıştır. Ayrıca verilerin taranması ve normallik testleri için SPSS 26 programı kullanılmıştır.

Şekil 1. Araştırma Modeli

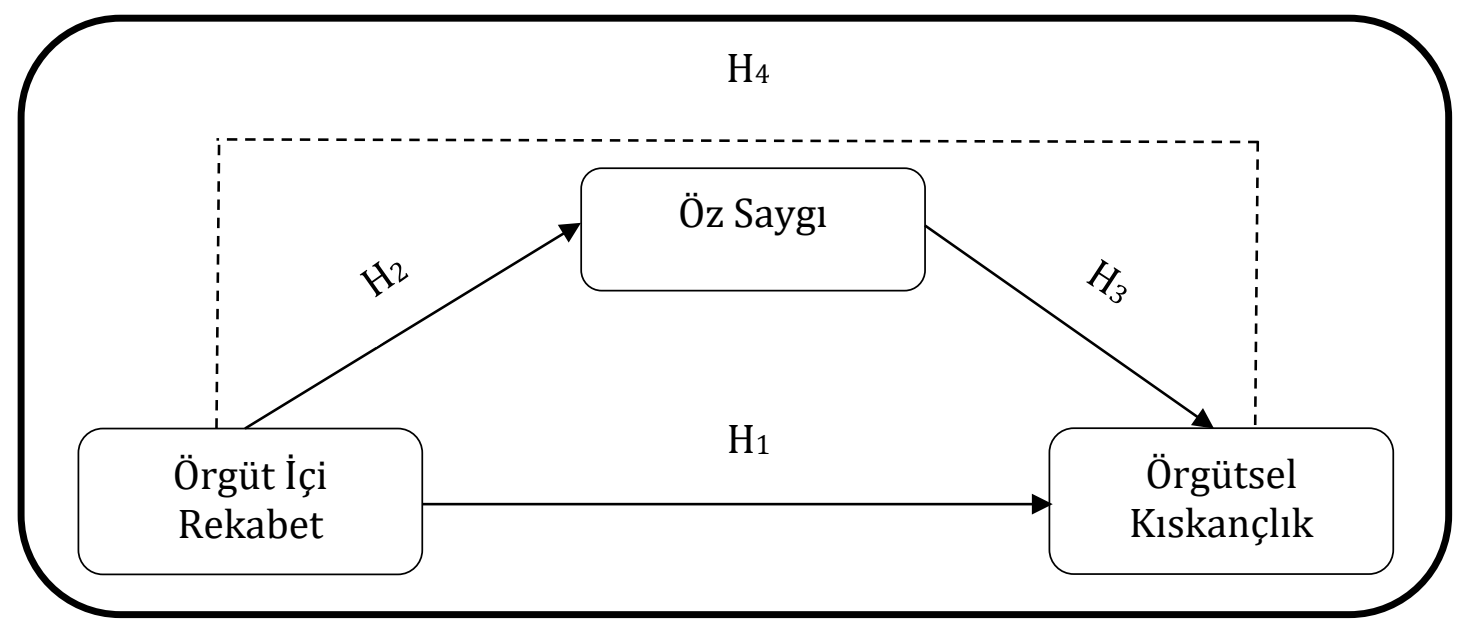




\section{1. Örneklem}

Araştırmanın ana kitlesi, uluslararası operasyonları da bulunan Türk menşeili havayolu işletmelerinin çalışanlarından oluşmaktadır. Araştırmanın evreninde bulunan çalışan sayısı bilinmemektedir ve çalışanların tamamına ulaşılması mümkün olmadığından örnekleme yapılmıştır. Örneklem zaman baskısı altında yoğun ve yorucu bir tempoda çalışan havayolu çalışanlarından oluşmaktadır. Bu seçimdeki temel amaç, sektörde firmalar arasından yaşanan yoğun rekabetin çalışanlar arasında da rekabete sebep olabileceği düşüncesidir. Ayrıca sektör birçok operasyonun başarılmasında insan unsurunu içerdiğinden insan ilişkilerinin önemli olduğu bir sektördür. Bu sebeple çalışanlar arasında rekabetin kıskançlı̆̆ da tetikleyebileceği öngörülmüştür. Örnekleme yöntemi olarak kartopu örnekleme yöntemi kullanılmıştır. Buna göre araştırmacı ilk araştırma grubu veya bireyleri bulunduktan sonra, bu bireyler aracılığıyla yeni deneklere ulaşmaktadır (Noy, 2008). $\mathrm{Bu}$ yöntemin tercih sebebi, konuyla doğrudan ilgili çalışanlara ulaşılmasının hedeflenmesidir. Böylece doğrudan rekabet içerisinde olan veya kıskançlığa maruz kalan (veya başkalarını kıskanan) çalışanlara ulaşılmıștır.

Elektronik ortamda hazırlanan anket formu ilk etapta iletişime geçilen 50 çalışana iletilmiştir. Bu çalışanlardan konuyla ilgili olanlar anketi doğrudan cevaplayıp, konuyla ilgisi olmadığını düşünenler anketi elektronik ortamda ilgili arkadaşlarına yönlendirmiştir. Böylece 256 çalışana ulaşılmıştır. Katılımcıların \%59,84'ü kadın $(n=152)$, \%40,16'sı erkektir $(n=102)$. Tamamı hava hizmetlerinde çalışan katılımcıların mevcut işyerlerinde çalıșma süresi 4,9 yıl iken, sektördeki çalıșma süresi ortalama 6,8 yıldır.

\section{2. Ölçüm Araçları}

Örgüt içi rekabet ölçeği: Örgüt içi rekabet algısını ölçmek için Mael ve Ashforth (1992) tarafından geliştirilen, Çiçek ve Söylemez (2020) tarafından Türkçeye uyarlanan ölçek kullanılmıştır. 8 maddeden oluşan ölçeğin 3. ve 7. maddeleri ters kodlanmıştır. Örnek ölçek maddeleri: "Kurumumda yoğun bir rekabet ortamı vardır" ve "Yöneticiler kurum içerisindeki rekabeti teşvik etmez." şeklindedir.

Öz saygı ölçeği: Öz saygıyı ölçmek için Steinfield, Ellison ve Lampe (2008) tarafından geliştirilen öz saygı ölçeği kullanılmıştır. 7 maddeden oluşan ölçeğin 3. ve 5. maddeleri ters kodlanmıştır. Hazırlanan anket formunda bu sıralamaya sadık kalınmıştır. Örnek ölçek ifadeleri: "Bütün olarak değerlendirildiğinde bașarısız hissetmeye meyilliyim (R)" ve "Diğer insanların yaptığı şeyleri ben de yapabilirim" tarzındadır.

Örgütsel kıskançlık ölçeği: Örgütsel kıskançlığı ortaya koymak için Vecchio (2005) tarafından geliştirilen ve "kıskanıldığını düşünme" ile "başkalarını kıskanma" olmak üzere 2 boyuttan oluşan ölçek kullanılmıştır. Kıskanıldığını düşünme boyutu 3 maddeden oluşmaktadır. 3 maddeden oluşan kıskanıldığını düşünme boyutunun örnek maddesi "İşteki başarım bazen iş arkadaşlarımın zoruna gidiyor" şeklindedir. 5 maddeden oluşan başkalarını kıskanma boyutunun örnek maddesi ise "Yöneticimin, iş arkadaşlarımın çabalarına verdiği değeri benim çabalarıma vermediğini düşünüyorum" tarzındadır.

Kullanılan ölçeklerin tamamı 5'li Likert tipindedir ve ölçek aralıkları 1-Hiç Katılmıyorum, 5Tamamen Katılıyorum şeklinde kodlanmıştır. Ortak yöntem yanlılığını ve sosyal arzu edilirlik yanlılığını en aza indirmek için anket, Podsakoff, Mackenzie ve Podsakoff (2003) tarafından yapılan önerilere göre tasarlanmıştır. Buna göre ankete çalışmanın gizliliğini, katılımın gönüllüğünü, doğru veya yanlış cevapların olmadığını ve değişkenlerin tanımlandığı bir kapak eklenmiştir. Böylece çalışanların kendi kimliklerini veya çalıştıkları iş yerlerini açıklayacak herhangi bir bilgiyi vermeyerek daha rahat cevaplamaları sağlanmıştır. 
Çalışmada ortak yöntem yanlılığı hatası olmadığını tespit etmek için toplanan veriler Harman'ın (1960) tek-faktör testine tabi tutulmuştur. Döndürme yöntemi uygulanmadan tek faktör altında incelenen verilerin açıklanan varyansı \%27,3'tür. Bu değer kabul edilebilir sınır olan \%50'nin oldukça altında olduğundan çalışmada ortak yöntem yanlılığı hatasının olmadığına kanaat getirilmiştir (Kline, 2016).

\subsection{Bulgular}

\subsection{1. Ölçüm Modeli}

Ölçüm modeli kurulmadan önce veriler SPSS 26 programında taranmıştır. Öncelikle eksik olan değerlere ortalamalar atanarak değişkenler içerisindeki eksik veriler giderilmiştir. Daha sonra değişkenlerin normal dağılım gösterip göstermediği kontrol edilmiştir. Bunun için tek değişkenli ve çok değişkenli normallik dağılımları kontrol edilmiştir. Öncelikle her değişkenin çarpıklık ve basıklık değerlerine bakılmıştır. Değişkenler için basıklık değerlerinin-0.321 ile -1.121, çarpıklık değerlerinin ise -0.911 ile 0.180 arasında olduğu görülmüştür. Bu değerler Kline (2015) tarafından önerilen sınırlar içerisinde olduğundan tek değişkenli normallik kriterinin sağlandığı belirlenmiştir. Çok değişkenli normallik dağılımı testi için Mardia (1970) katsayısından yararlanılmıştır. Raykov ve Marcoulides (2008), çok değişkenli normallik için Mardia basıklık katsayısının $p(p+2)$ denkleminden küçük olması gerektiğini belirtmiştir. Bu denklemde $p$ değişken sayısını ifade etmektedir. Çalışmada 23 gözlenen değişken olduğundan denklem 575 olarak saptanmıștır. Mardia basıklık değeri 181,02 olarak ölçülmüştür. Bu değer 575'ten küçük olduğundan çalışmada çok değişkenli normallik dağılımının da sınırlar içerisinde olduğu görülmüştür.

Kullanılan ölçeklerin yapı geçerliliği ile güvenilirliğini test etmek (Anderson ve Gerbing, 1988) ve uyuşum, ayrışım geçerliliklerini doğrulamak (Fornell ve Larcker, 1981) amacıyla MPlus 8.4 programı ile bir ölçüm modeli kurulmuştur. Fornell ve Larcker (1981) yapısal modelde anlamlı bir ilişki için test yapmadan önce, ölçüm modelinin yeterli düzeyde bir geçerlilik ve güvenilirliğe sahip olduğunun kanıtlanması gerektiğini savunmuştur. Bunun için ölçek maddelerinin 0,50'den daha yüksek bir faktör yüküne sahip olması, varyans tahmin değerlerinin (AVE) 0.50'den yüksek olması, kompozit güvenilirlik (CR) değerinin 0,60'tan büyük olması, ayrıca Cronbach's $\alpha$ değerinin kabul edilebilir sınırlar içerisinde olması beklenmektedir. Bu amaçla kurulan ölçüm modelinin iyilik uyum indekslerinin kabul edilebilir sinırlar içerisinde (Hu ve Bentler, 1999) olduğu görülmüştür $\chi^{2} / \mathrm{df}=$ 2,329; RMSEA = 0,053; NFI = 0,941; TLI = 0,946; CFI = 0,974; SRMR = 0,049. Fornell ve Larcker (1981) AVE ve CR hesaplanması için aşağıdaki formülleri önermiştir.

$$
\begin{gathered}
A V E=\frac{\sum_{i=1}^{n} \lambda^{2}}{\mathrm{n}} \\
C R=\frac{\left(\sum_{i=1}^{i} \lambda_{i}\right)^{2}}{\left(\sum_{i=1}^{i} \lambda_{i}\right)^{2}+\left(\sum_{i=1}^{i} 1-\lambda_{i}^{2}\right)}
\end{gathered}
$$

Formüllere göre MS Excel 2019 programı yardımıyla hesaplanan ölçeklere ilişkin uyuşum ve ayırt edici geçerlilik ile faktör yükleri ve güvenilirlik analizi sonuçları Tablo 1'de verilmiştir. 
Tablo 1. Geçerlilik ve Güvenilirlik Analizi Sonuçları

\begin{tabular}{|c|c|c|c|c|c|c|}
\hline \multicolumn{2}{|c|}{ Değişkenler } & Maddeler & $\begin{array}{c}\text { Faktör } \\
\text { Yükü }\end{array}$ & AVE & CR & Alpha \\
\hline \multirow{8}{*}{\multicolumn{2}{|c|}{$\begin{array}{l}\text { Örgüt İçi Rekabet } \\
\text { Ölçeği }\end{array}$}} & ÖİR1 & 0,721 & \multirow[t]{8}{*}{0,528} & \multirow[t]{8}{*}{0,897} & \multirow[t]{8}{*}{0,812} \\
\hline & & ÖİR2 & 0,836 & & & \\
\hline & & ÖİR3 (R) & 0,544 & & & \\
\hline & & ÖİR4 & 0,846 & & & \\
\hline & & ÖİR5 & 0,763 & & & \\
\hline & & ÖİR6 & 0,693 & & & \\
\hline & & ÖİR7 (R) & 0,514 & & & \\
\hline & & ÖİR8 & 0,815 & & & \\
\hline \multirow{7}{*}{\multicolumn{2}{|c|}{ Öz Saygı Ölçeği }} & ÖS1 & 0,784 & \multirow{7}{*}{0,554} & \multirow[t]{7}{*}{0,895} & \multirow[t]{7}{*}{0,804} \\
\hline & & ÖS2 & 0,836 & & & \\
\hline & & ÖS3 (R) & 0,634 & & & \\
\hline & & ÖS4 & 0,912 & & & \\
\hline & & ÖS5 (R) & 0,581 & & & \\
\hline & & ÖS6 & 0,723 & & & \\
\hline & & ÖS7 & 0,686 & & & \\
\hline \multirow{8}{*}{ 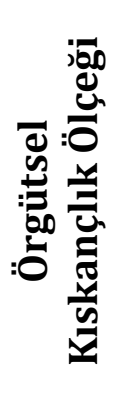 } & \multirow{3}{*}{$\begin{array}{l}\text { Kıskanıldığını } \\
\text { Düşünme } \\
\text { Boyutu }\end{array}$} & KD1 & 0,832 & \multirow[t]{3}{*}{0,498} & \multirow[t]{3}{*}{0,745} & \multirow[t]{3}{*}{0,711} \\
\hline & & KD2 & 0,648 & & & \\
\hline & & KD3 & 0,618 & & & \\
\hline & \multirow{5}{*}{$\begin{array}{l}\text { Başkalarını } \\
\text { Kıskanma } \\
\text { Boyutu }\end{array}$} & BK1 & 0,781 & \multirow[t]{5}{*}{0,561} & \multirow[t]{5}{*}{0,864} & \multirow[t]{5}{*}{0,798} \\
\hline & & $\mathrm{BK} 2$ & 0,648 & & & \\
\hline & & BK3 & 0,683 & & & \\
\hline & & BK4 & 0,814 & & & \\
\hline & & BK5 & 0,804 & & & \\
\hline
\end{tabular}

Tablo 1'den görüleceği üzere tüm ölçek maddeleri 0,50 değerinin üzerindedir. Örgütsel kıskançlık ölçeğinin "kıskanıldığını düşünme" boyutunun dışında tüm ölçeklerin AVE değeri kritik eşik olan 0,50 değerinin üzerindedir. Kıskanıldığını düşünme boyutunun AVE değeri 0,50 eşiğinin biraz altında olması konusunda Fornell ve Larcker (1981) CR değerinin kontrol edilmesini önermiştir. Buna göre araştırmacılar CR değeri 0,70 üzerinde olan yapılarda ölçek maddesi çıkarılmaması gerektiğini savunmuştur. Buradan hareketle kıskanıldığını düşünme boyutundan herhangi bir madde çıkarılmadan analizlere devam edilmiştir. Bunun dışında tüm CR ve Cronbach $\alpha$ değerleri 0,70'ten yüksek olduğu için ölçeklerin güvenilirlik sınırını da aştığı tespit edilmiştir. Bu sonuçlara göre ölçeklerin uyuşum geçerliliği ve güvenilirliğinin kabul edilebilir sınırlar içerisinde olduğu görülmüştür. Ayrışım geçerliliği için AVE değerlerinin karekökünün değişkenler arasındaki korelasyon değerinden yüksek olması gerekmektedir (Fornell ve Larcker, 1981). Değişkenler arası korelasyon, AVE değerlerinin karekökü, ortalama ve standart sapma değerleri Tablo 2'de verilmiştir. 
Tablo 2. Tanımlayıcı İstatistikler

\begin{tabular}{|l|c|c|c|c|c|c|}
\hline & Ort. & SS. & $\mathbf{1}$ & $\mathbf{2}$ & $\mathbf{3}$ & $\mathbf{4}$ \\
\hline 1. ÖİR & 3,18 & 0,867 & $\mathbf{( 0 , 7 2 7 )}$ & & & \\
\hline 2. ÖS & 3,44 & 0,810 & $-0,541^{* * *}$ & $\mathbf{( 0 , 7 4 4 )}$ & & \\
\hline 3. KD & 3,87 & 1,101 & $0,483^{* * *}$ & $-0,389^{* * *}$ & $\mathbf{( 0 , 7 0 6 )}$ & \\
\hline 4. BK & 3,51 & 0,972 & $0,671^{* * *}$ & $-0,241^{* *}$ & $0,581^{* * *}$ & $\mathbf{( 0 , 7 4 9 )}$ \\
\hline
\end{tabular}

${ }^{* *} \mathbf{p}<0,01 ;{ }^{* *} \mathbf{p}<0,001 ;$ ÖİR = Örgüt İçi Rekabet; ÖS = Öz Saygı; KD = Kıskanıldığını Düşünme; BK = Başkalarını Kıskanma; Parantez İçi Koyu Değerler $=\sqrt{\text { AVE }}$

Tablo 2'den de anlaşlacağı üzere parantez içerisinde verilen AVE değerlerinin karekökünün değişkenler arasındaki korelasyon katsayısını aştığı görülmektedir. Buna göre değișkenler arasında ayrışım geçerliliği açısından Fornell ve Larcker (1981) kriterlerine göre herhangi bir sorun olmadığı tespit edilmiştir. Bununla birlikte son yıllarda yapılan araştırmalarında Henseler vd. (2015) varyans temelli yapısal eşitlik modellerinde de ayrışım geçerliliğini test etmek için korelasyonların heterotrait-monotrait oranının (HTMT) hesaplanmasını önermiştir. Yapılar arasında ölçülen bu değerin her bir değişken için 0.85'ten küçük olması gerekmektedir. Yapılan analizlerde ölçülen HTMT değerlerinin 0.85 'ten oldukça küçük olduğu $(0,385-0,411)$ tespit edilmiştir. Buna göre çalışmanın geçerlilik ve güvenilirlik açısından herhangi bir sorun teşkil etmediği sonucuna ulaşılmıştır. Son olarak çalışmada çoklu bağlantı sorunu olup olmadığı kontrol edilmiştir. Bu amaçla değişkenler arasında çoklu doğrusal regresyon analizi yapılmıştır. Yapılan regresyon analizi sonuçlarına göre elde edilen VIF değerlerinin 1,031 ile 1,386 arasında olduğu tespit edilmiştir. Bu sonuçlara göre çalışmada çoklu doğrusal bağlantı sorunu olmadığına kanaat getirilmiştir (Craney ve Surles, 2002). Değerler aşağıdaki gibidir.

Tablo 3. Çoklu Bağlantı Analizi

\begin{tabular}{|l|c|c|}
\hline \multicolumn{1}{|c|}{ Değișken } & Tolerans & VIF \\
\hline ÖİR & 0,788 & 1,269 \\
\hline ÖS & 0,970 & 1,031 \\
\hline KD & 0,886 & 1,129 \\
\hline BK & 0,722 & 1,386 \\
\hline $\begin{array}{l}\text { ÖİR = Örgüt İçi Rekabet; ÖS = Öz Saygı; KD = Kıskanıldığını Düşünme; BK = Başkalarını } \\
\text { Kıskanma }\end{array}$ \\
\hline
\end{tabular}

\subsubsection{Yapisal Model}

Araştırmada kurulan hipotezleri test etmek için yapısal eşitlik modeli kurulmuştur. Kurulan bu modelin uyum indekslerinin kabul edilebilir sınırlar içerisinde (Hu ve Bentler, 1999) olduğu görülmüștür $\chi^{2}=381,501(163), \chi^{2} / \mathrm{df}=2,340$; RMSEA = 0,072; NFI =0,902; TLI = 0,931; CFI =0,940. Kurulan model sonucunda elde edilen doğrudan etki analizi sonuçları Tablo 3'teki gibidir. 
Tablo 4. Doğrudan Etki Analizi Sonuçları

\begin{tabular}{|c|c|c|c|c|}
\hline Hipotezler & Katsayı ${ }^{1}$ & S.H. & К.0. & $p$ \\
\hline H1a: Örgüt İçi Rekabet $\rightarrow$ Kıskanıldığını Düşünme & 0,414 & 0,051 & 6,144 & 0,000 \\
\hline H1b: Örgüt İçi Rekabet $\rightarrow$ Bașkasını Kıskanma & 0,321 & 0,059 & 8,181 & 0,000 \\
\hline $\mathrm{H}_{2}:$ Örgüt İçi Rekabet $\rightarrow$ Öz saygı & $-0,283$ & 0,032 & $-4,132$ & 0,003 \\
\hline Hзa: Öz saygı $\rightarrow$ Kıskanıldığını Düşünme & $-0,310$ & 0,044 & $-4,831$ & 0,001 \\
\hline H3b: Öz saygı $\rightarrow$ Bașkasını Kıskanma & $-0,641$ & 0,062 & $-9,861$ & 0,000 \\
\hline
\end{tabular}

Kurulan yapısal eşitlik modelindeki ilişkiler incelendiğinde örgüt içi rekabetin kıskanıldığını düşünme $(\beta=0,414 ; p<0.001)$ ve başkasını kıskanma $(\beta=0,321 ; p<0.001)$ değişkenleri üzerinde pozitif ve anlamlı öz saygı $(\beta=-0,283 ; p<0.01)$ üzerinde ise negatif ve anlamlı bir etkiye sahip olduğu görülmüştür. Öz saygının ise kıskanıldığını düşünme $(\beta=-0,310 ; p<0.01)$ ve başkasını kıskanma $(\beta$ $=-0,641 ; \mathrm{p}<0.001$ ) değișkenleri üzerinde negatif yönlü ve anlamlı bir etkiye sahip olduğu belirlenmiştir. Araştırmanın bu bulgularına göre "Hıa: Örgüt içi rekabet kıskanıldığını düşünmeyi pozitif yönde etkiler", "H1b: Örgüt içi rekabet başkalarını kıskanmayı pozitif yönde etkiler", "H2: Örgüt içi rekabet öz saygıyı negatif yönde etkiler”, "Hзa: Öz saygı kıskanıldığını düşünmeyi negatif yönde etkiler" ve "Hзb: Öz saygı başkasını kıskanmayı negatif yönde etkiler" hipotezleri desteklenmiştir.

Modeldeki aracı etki analizlerini test etmek için Baron ve Kenny (1986) tarafından önerilen adımlar izlenmiştir. Aracılık analizi, kitle parametresine ilişkin güven aralığının hesaplanmasına olanak sağlayan bootstrap yöntemi ile yapılmıștır. Araștırmada bootstrap örneklem büyüklügü 5000 olarak belirlenmiştir. Aracılık analizi sonuçları Tablo 4'te paylaşılmıştır.

Tablo 5. Dolaylı Etki Analizi Sonuçları

\begin{tabular}{|c|c|c|c|c|}
\hline Hipotezler & $\begin{array}{c}\text { Doğrudan } \\
\text { Etki }^{1}\end{array}$ & $\begin{array}{c}\text { Doğrudan } \\
\text { Etki }^{2}\end{array}$ & Dolaylı Etki & $\begin{array}{l}\text { Aracilık } \\
\text { Durumu }\end{array}$ \\
\hline $\mathrm{H}_{4 \mathrm{a}}:$ ÖR $\rightarrow$ ÖS $\rightarrow \mathrm{KD}$ & $0,414^{* * *}$ & $0,326^{*}$ & $0,141^{* *}$ & Kismi Araci \\
\hline $\mathrm{H}_{4 \mathrm{~b}}:$ ÖR $\rightarrow$ ÖS $\rightarrow \mathrm{BK}$ & $0,321^{* * *}$ & 0,139 (ns) & $0,285^{* * *}$ & Tam Aracı \\
\hline
\end{tabular}

$\mathrm{H}_{4 a}$ hipotezi öz saygının, örgüt içi rekabet ile kıskanıldığını düşünme değişkenleri arasındaki ilişkiye aracılık edeceğini öngörmekteydi. Yapılan analiz sonucunda öz saygı değișkeninin modele girmesi durumunda örgüt içi rekabet ile kıskanıldığını düşünme arasındaki ilişkinin gücünü azalttığı görülmüștür. Ayrıca bootstrap analizi neticesinde anlamlı bir dolaylı etki katsayısı hesaplanmıștır. $\mathrm{Bu}$ sonuçlara göre öz saygının ilişkiye kısmi aracılık ettiği görülmüştür ve "H4a: Öz saygı örgüt içi rekabet ile kıskanıldığını düşünme arasındaki ilişkiye aracılık eder" hipotezi kabul edilmiştir. $\mathrm{H}_{4 \mathrm{~b}}$ hipotezi ise öz saygının, örgüt içi rekabet ile başkasını kıskanma değişkenleri arasındaki ilişkiye aracılık edeceğini öngörmekteydi. Yapılan analiz sonucunda öz saygı değişkeninin, örgüt içi rekabet ile başkasını kıskanma değişkenleri arasındaki ilişkiyi anlamsızlaştırdığı görülmüştür. Ayrıca bootstrap analizi ile anlamlı bir dolaylı etki katsayısı elde edilmiştir. Bu sonuca göre öz saygının bu ilişkide tam aracılık rolüne sahip olduğu görülmüştür ve "H4b: Öz saygı örgüt içi rekabet ile başkasını kıskanma arasındaki ilişkiye aracılık eder” hipotezi kabul edilmiştir. 


\section{TARTIŞMA VE SONUÇ}

Hemen her organizasyonda gördüğümüz rekabetçi ortam çoğu zaman iyi bir şey olarak görülmekte hatta yöneticiler tarafından teşvik edilmektedir (Arnold ve diğerleri, 2009; Barmby ve diğerleri, 2016; Brown ve diğerleri, 1998; Elliot ve diğerleri, 2018; Fletcher ve Nusbaum, 2010). Bu durum günümüz verimlilik ve kârlılık üzerine kurulu işletmecilik ortamında anlaşılabilir olsa da bunun bireyler arasındaki husumeti tetikleyip çatışma, intikam, sinizm, dedikodu, kıskançlık gibi negatif tutumlara neden olabileceği göz ardı edilmemelidir. Buna rağmen yöneticilerin çoğu zaman işyerinde kaos ortamı yaratarak bundan yararlanmaya çalıştığı görülmektedir. Buradan hareketle bu çalışmada çoğu kişi için olumlu bir durum olarak görülen rekabetçi ortamın, istenmeyen sonuçlarından biri olarak nitelendirebileceğimiz örgütsel kıskançlığa olan etkisinin ortaya konulması amaçlanmıştır. Ayrıca, rekabet ve kıskançlık arasındaki ilişkide bireylerin öz saygısının aracılık rolünün ortaya konulması hedeflenmiştir.

Araştırmanın amacı doğrultusunda oluşturulan hipotezleri test etmek için nicel araştırma yöntemlerinden yararlanılmıştır. Yapılan analizlerin sonuçlarına göre örgüt içi rekabetin, örgütsel kıskançlığın alt boyutları olan kıskanıldığını düşünme ve başkasını kıskanma boyutları üzerinde pozitif yönlü bir etkisinin olduğu görülmüştür. Başka bir deyişle örgüt içi rekabetin kıskançlığı artırdığı tespit edilmiştir. Çalışmanın bu bulgusu Ghadi'nin (2018) araștırması ile paralellik göstermektedir. Buradan da anlaşlacağı üzere sürekli olumlu olarak görülen rekabet ve rekabetçi ortam aslında organizasyon içerisinde kıskançlığa zemin oluşturmaktadır. Nitekim Stanne, Johnson ve Johnson (1999) bu konuda örgüt içi rekabettense iş birliği içerisinde çalışmanın daha faydalı olduğunu savunmaktadır. Parks, Rumble ve Posey (2002) de bunu destekler nitelikte kıskanç insanların daha az işbirlikçi olduğunu belirtmiştir.

Araştırmanın bir diğer bulgusuna göre, örgüt içi rekabetin öz saygıyı azalttığı sonucuna ulaşılmıștır. Literatürde daha önce yapılmış çalışmaların (Bonham, 2013; Thompson ve diğerleri, 2016) sonuçlarına göre de kıskançlık öz saygıyı azaltan bir olgudur. Pierce vd. (1993) çalışmasında örgüt temelli öz saygının artmasının çalışanların iş yeri memnuniyetini ve örgütsel bağlılığını arttırdığı sonucuna varmıştır. Erez ve Judge (2001) ise öz saygının çalışan motivasyonu ve memnuniyetindeki merkezi konumu hakkında çalışma yürütmüştür. Bu çalışmada öz saygının kontrol odağl, duygusal istikrar ve genelleştirilmiş öz yeterlilik ile çalışan performansı ve memnuniyeti üzerinde önemli ve tutarlı etkileri olduğu sonucuna ulaşmıştır. Pierce ve Gardner (2004) çalışma ortamı yapıları ve yönetim uygulamalarının (teknoloji, katılımcı liderlik ve yönetim uygulamaları, iş tasarımı vb.) çalışanların kendilerini yönlendirme ve otokontrol eğilimlerini arttırdığı ve bu sonucun da örgüt temelli öz saygı ile ilişkili olduğu sonucuna varmıștır. Bu çalışmalardan da anlaşılacağı üzere bireylerin öz saygısı gerek kendi psikolojik tatminleri gerekse de organizasyondaki başarıları açısından oldukça önemli bir unsurdur. Bu nedenle kıskançlığın öz saygıya zarar vermesi üzerinde düşünülmesi gereken bir sonuç olarak karşımıza çıkmaktadır.

Çalışmanın bir diğer bulgusu, öz saygının kıskanıldığını düşünme ve başkalarını kıskanma üzerinde negatif bir etkiye sahip olduğu yönündedir. Başka bir deyişle öz saygısı yüksek olan çalışanlar işyerinde hem başkalarını kıskanma davranıșı sergilememekte hem de kıskanıldığını düşünmemektedir. Neff'e göre (2003) öz saygl, bireyin kendine saygı duyması, kendini değerli görmesi, kendini diğerlerinden daha iyi görmemekle birlikte kesinlikle daha kötü görmemesidir. Bu tanımlamadan da anlaşılacağı üzere, aslında bireyin kendini değerli görmesi başkalarına olan bakışını da etkilemektedir. Bu durumu sadece kıskançlıkla da sınırlandırmamak gerekmektedir çünkü öz saygısı yüksek bireyler karşıdakine zarar verici her türlü davranıştan kaçınabilmektedir.

Araştırmada öz saygının, örgüt içi rekabet ile kıskanıldığını düşünme ve başkasını kıskanma arasındaki ilişkiye aracılık ettiği sonucuna ulaşılmıştır. Başka bir deyişle öz saygısı yüksek bireyler 
rekabet ortamında olsalar dahi başkalarını kıskanmamakta veya kıskanıldığını düşünmemektedir. Öz saygı, bireyin kendisiyle ilgili güçlü fikirlere sahip olması (Telfer, 2010) ve hakları ile saygınlığı açısından kendini başkalarına eşit görme durumudur (Statman, 2000). Bu nedenle öz saygısı yüksek bireylerin kıskanma gibi bir davranış sergilemesi pek beklenebilir bir durum değildir. Araştırmanın bulguları da bu görüşleri destekler niteliktedir.

Çalışmada yönetici ve çalışanlara birtakım önerilerde bulunulmaktadır. Bu öneriler aşağıdaki gibidir.

- Rekabetçi ortamlar her ne kadar performansı artırıyor gibi görünse de uzun vadede çalışanlar arasında istenmeyen sorunlara sebep olabilmektedir. Çalışanlar arasındaki rekabetin zaman zaman birbirlerine zarar vermeye kadar uzanabilecek durumlara neden olabileceği göz önünde bulundurularak, organizasyonlarda rekabetten ziyade iş birliği teşvik edilmelidir.

- Hizmet sektörü doğası gereği birbirini tamamlayan süreçlerden oluşmaktadır. Burada rekabetin yaşanması organizasyona çoğu zaman katkı sunmamaktadır. Bu nedenle işletmeler rekabeti diğer firmalara yöneltip çalışanlara daha üstün bir amaç sağlayabilir. Başka bir deyişle örgüt içi rekabetten ziyade, rekabet hissi örgütler arası hizmet yarışına çevrilmelidir.

- Öz saygısı yüksek bireylerin olumsuz tavırlarının törpüleneceği aşikardır. Bu nedenle bireylerin öz saygısını yitirmelerine neden olabilecek olumsuz tavırlardan kaçınılmalıdır. Özellikle yöneticilere bu konuda büyük iş düşmektedir. Bireylerin kendilerine olan saygılarını yitirtebilecek tavırlardan kaçınılmalı, onlara örgüt için değerli oldukları hissettirilerek kendilerini değerli görmeleri sağlanmalıdır.

- Kıskanma duygusu karşı tarafa olduğu kadar bireyin kendisine de zarar verebilmektedir. Kıskanç bireyler sürekli karşılaştırma yapmak suretiyle kendi kafalarını meşgul edip, kendileri için de zararlı hale gelebilmektedir. Bu durumun önüne geçmek için iş ortamında başkaları ile kendini karşılaştırmaktansa, çalışanların kendi yaptıkları işe odaklanması daha makul bir yaklaşım olacaktır. Böylece başkalarına takılmadan yaptıkları iş daha anlamlı hale gelip, daha yüksek performans sergileyebileceklerdir.

Çalışmada her ne kadar kısıtlardan kaçınılmaya çalışılmışsa da araştırmanın birtakım sınırlılıklarının olduğu bilinmelidir. Öncelikle çalışmanın konusu olan rekabet, kıskançlık ve öz saygı gibi değişkenlerin bireyin sübjektif tutumuna dayandığı bilinmelidir. Cevaplar verilirken yanlılığın olabileceği göz önünde bulundurulmalıdır. Çalışmanın sadece hizmet sektöründe yapılmış olması bir diğer kısıtlılıktır çünkü örgüt içi rekabetin çıktıları üretim işletmeleri açısından aynı olmayabilir. Çalışma bulguları değerlendirilirken bu durum dikkate alınmalıdır. Bu kısıtlılıklar aynı zamanda gelecek çalışmalar için firsatları da beraberinde getirmektedir. Buradan hareketle gelecek çalışmalarda örneklem olarak özellikle üretim sektörünün belirlenmesi veya üretim ile hizmet sektörünün karşılaştırmalı olarak ele alınması tavsiye edilebilir. Bununla birlikte örgüt içi rekabet ile kıskançlık arasındaki ilişkide aracı değişken olarak öz düzenleme değişkeninin değerlendirilmesi önerilmektedir. Bununla birlikte bu ilişskiye dışarıdan etki edebilecek liderlik stillerinin de göz önünde bulundurulmasının ilgili literatüre katkı sunacağı düşünülmektedir. 


\section{KAYNAKÇA}

Aba, Y. A., ve Kulakaç, Ö. (2016). The revised conflict tactics scales (Cts2): Validity and reliability study. Bakırköy Tıp Dergisi / Medical Journal of Bakirkoy, 12(1), 33-43. Https://Doi.Org/10.5350/Btdmjb201612106

Ağraş, S., ve Kılınç, İ. (2015). Rekabetçi davranışların oluşmasında örgütsel yeteneklerin etkileri: Akdeniz ve ege bölgesi otellerine yönelik bir araștırma. Düzce Üniversitesi Sosyal Bilimler Enstitüsü Dergisi, 5(1), 50-80.

Anderson, J. C., ve Gerbing, D. W. (1988). Structural equation modeling in practice: A review and recommended two-step approach. Psychological Bulletin, 103(3), 411-423. Https://Doi.Org/10.1037/0033-2909.103.3.411

Andiappan, M., ve Dufour, L. (2020). Jealousy at work: A tripartite model. Academy of Management Review, 45(1), 205-229. Https://Doi.Org/10.5465/Amr.2016.0299

Arnold, T., Flaherty, K. E., Voss, K. E., ve Mowen, J. C. (2009). Role stressors and retail performance: The role of perceived competitive climate. Journal of Retailing, 85(2), 194-205. Https://Doi.Org/10.1016/J.Jretai.2009.02.002

Ashforth, B., ve Humphrey, R. H. (1995). Emotion in the workplace: A reappraisal. Human Relations, 48(2), 97-125. Https://Doi.Org/10.1177/001872679504800201

Baderin, A., ve Barnes, L. (2018). Risk and self-respect. British Journal of Political Science. 50(4), Https://Doi.Org/10.7910/Dvn/Aux9w1

Balkundi, P., ve Harrison, D. A. (2006).Les, leaders, and time in teams: Strong inference about network structure's effects on team viability and performance. Academy of Management Journal, 49(1), 49-68.

Barmby, T., Sessions, J. G., ve Zangelidis, A. (2016). Looking after number two? competition, cooperationand workplace interaction. Journal of Economic Behavior ve Organization, 131, 166-182. Https://Doi.Org/10.1016/J.Jebo.2016.08.001

Baron, R. M., ve Kenny, D. A. (1986). The moderator-mediator variable distinction in social psychological research: Conceptual, strategic, and statistical considerations. Journal of Personality and Social Psychology, 51(6), 1173-1182. Https://Doi.Org/10.1037/00223514.51.6.1173

Baumeister, R. F., Campbell, J. D., Krueger, J. I., ve Vohs, K. D. (2003). Does high self-esteem cause better performance, interpersonal success, Happiness or healthier lifestyles? Psychological Science in The Public Interest, 4(1), 1-44. Https://Doi.Org/10.1111/1529-1006.01431

Baumeister, R. F., Smart, L., ve Boden, J. M. (1996). Relation of threatened egotism to violence and aggression: The dark side of high self-esteem. Psychological Review, 103(1), 5-33.

Bayram Arlı, N., Aydemir, M., ve Çelik, E. (2018). Çalışan kıskançlığı ölçeğinin türkçe geçerlik ve güvenirlik çalışması. Isguc The Journal Of Industrial Relations and Human Resources, 20(4), 1-17. Https://Doi.Org/10.4026/İsguc.503880

Becker-Ritterspach, F., ve Dörrenbächer, C. (2011). An organizational politics perspective on intrafirm competition in multinational corporations. Management International Review, 51(4), 533-559. Https://Doi.Org/10.1007/S11575-011-0083-2 
Beersma, B., Hollenbeck, J. R., Humphrey, S. E., Moon, H., Conlon, D. E., ve Ilgen, D. R. (2003). Cooperation, competition, and team performance: Toward a contingency approach. Academy of Management Journal, 46(5), 572-590.

Bonham, A. (2013). The hidden nature of envy: antecedents and consequences of envy in the workplace (Unpuhlised doctoral dissertation). Auckland, The University of Auckland.

Boxill, B. R. (1976). Self-respect and protest. Philosophy ve Public Affairs, 6(1), 58-69. Http://Www.Jstor.Org/Stable/2265062

Brown, S. P., Cron, W. L., ve Slocum, J. W. (1998). Effects of trait competitiveness and perceived intraorganizational competition on salesperson goal setting and performance. Journal of Marketing, 62, 88-98.

Buunk, A. P., ve Dijkstra, P. (2015). Rival characteristics that provoke jealousy: A study in iraqi $\begin{array}{llll}\text { kurdistan. } & \text { Evolutionary } \quad \text { Behavioral } & \text { Sciences, } & \text { 9(2), }\end{array}$ Https://Doi.Org/10.1037/Ebs0000030

Certel, Z., Bahadır, Z., ve Sönmez, G. T. (2013). Investigation of empathy and self- esteem in decision making and decision- making styles among those who played team sports. Beden Eğitimi ve Spor Bilimleri Dergisi, 7(1), 16-27. Https://Dergipark.Org.Tr/Tr/Pub/Bsd/713022

Clark, R. A., ve Goldsmith, R. E. (2005). Market mavens: Psychological influences. Psychology ve Marketing, 22(4), 24. Https://Doi.Org/10.1002/Mar.20060

Collins, R. L. (2000). Among the better ones. In J. Suls and L. Wheeler (Eds.) Handbook of Social Comparison (pp. 159-171). Springer: Boston, MA.

Cohen-Charash, Y., ve Mueller, J. S. (2007). Does perceived unfairness exacerbate or mitigate interpersonal counterproductive work behaviors related to envy? Journal of Applied Psychology, 92(3), 666-680. Https://Doi.Org/10.1037/0021-9010.92.3.666

Coulter, M. K. (2013). Strategic management in action (6th Ed). Boston: Pearson.

Craney, T. A., ve Surles, J. G. (2002). Model-dependent variance inflation factor cutoff values. Quality engineering, 14(3), 391-403. Https://Doi.Org/10.1081/Qen-120001878

Crocker, J., ve Major, B. (1989). Social stigma and self-esteem: The Self-protective properties of stigma. Psychological Review, 96(4), 608-630.

Crusius, J., ve Lange, J. (2014). What catches the envious eye? Attentional biases within malicious and benign envy. Journal of Experimental Social Psychology, 55, 1-11. Https://Doi.Org/10.1016/J.Jesp.2014.05.007

Çiçek, B., ve Söylemez, M. (2020). Sosyal karşılaştırma bakış açısından dedikodu, rekabet ve etik iklim ilişkisi. International Journal of Management Economics and Business, 16(3), 639-656. Https://Doi.Org/10.17130/İjmeb.798529

Daher, D. M., ve Cohen, M. (1979). Jealousy workshop: A Conceptual base and format. The Personnel and Guidance Journal, 57(9), 480-483. Https://Doi.Org/10.1002/J.21644918.1979.Tb05443.X

Demirel, Y., ve Karadal, H. (2007). Örgüt kültürünün örgüt içi bireysel becerilerin kullanımına etkisi üzerine bir araştırma. Süleyman Demirel Üniversitesi İktisadi ve İdari Bilimler Fakültesi Dergisi, 12(3), 253-270. Https://Dergipark.Org.Tr/Tr/Pub/Sduiibfd/223250 
Desteno, D. A., ve Salovey, P. (1996). Evolutionary origins of sex differences in jealousy? Questioning the "fitness" of the model. Psychological Science, 7(6), 367-372. Https://Doi.Org/10.1111/J.1467-9280.1996.Tb00391.X

Deutsch, M., Bierhoff, H. W., Cohen, R. L. ve Greenberg, J. (Ed.)., (1986). Cooperation, conflict, and justice. Justice İn Social Relations (Ss. 3-18). Springer Us. Https://Doi.Org/10.1007/978-14684-5059-0_1

Dillon, R. (2019). Self-respect and self-esteem. International Encyclopedia of Ethics (Ss. 1-12). John Wiley ve Sons, Ltd. Https://Doi.Org/10.1002/9781444367072.Wbiee221.Pub2

Dillon, R. S. (1997). Self-respect: Moral, emotional, political. ethics, 107(2), 226-249. Https://Doi.Org/10.1086/233719

Dinçer, Ö. (2013). Örgüt geliştirme. İstanbul: Alfa Basım Yayım.

Dogan, K., ve Vecchio, R. P. (2001). Managing envy and jealousy in the workplace. Compensation ve Benefits Review, 33(2), 57-64. Https://Doi.Org/10.1177/08863680122098298

Doppelt, G. (2009). The Place of self-respect in a theory of justice. Inquiry: An interdisciplinary Journal of Philosophy, 2(52), 127-154. Https://Doi.Org/10.1080/00201740902790219

Duffy, M. K., ve Shaw, J. D. (2000). The salieri syndrome: Consequences of envy in groups. Small Group Research, 31(1), 3-23. Https://Doi.Org/10.1177/104649640003100101

Dunn, J. R., ve Schweitzer, M. E. (2004). Too good to be trusted? relative performance, envy and trust. Academy of Management Proceedings, 2004(1), B1-B6. Https://Doi.Org/10.5465/Ambpp.2004.13862773

Durmuş, İ. (2021), Kurum yöneticilerinin etik liderlik davranışları ile çalışanların kuruma ve yöneticilerine olan sadakatlerinin imrenme ve kıskançlık davranışları moderatörlügünde akademik başarı çabaları üzerindeki olası etkilerinin incelenmesi, Doktora Tezi, Gümüşhane

Eginli, A. T., ve Bitirim, S. (2010). Örgütlerde kişilerarası ilişkilerde bir problem: Psikolojik yıldırma (Aktörlerin ve kurbanların iletişim davranışları). Muğla Üniversitesi Sosyal Bilimler Enstitüsü Dergisi, 24, 45-66. Https://Dergipark.Org.Tr/Tr/Pub/Musbed/250537

Elliot, A. J., Jury, M., ve Murayama, K. (2018). Trait and perceived environmental competitiveness in $\begin{array}{llll}\text { achievement situations. Journal of Personality, 86(3), 367. } & \text {. }\end{array}$ Https://Doi.Org/10.1111/Jopy.12320

Erdoğmuş, N. (1999). Kişilerde iç çatışma nedeni olarak rekabet-işbirliği ikilemi. Bilgi Sosyal Bilimler Dergisi, 1, 45-60.

Eren, V. (2003). Kamu yönetiminde rekabet, rekabetin kurumsallaştırılması ve rekabet mekanizmaları. Ankara Üniversitesi Sbf Dergisi, 58(4), 83-105.

Erez, A., ve Judge, T. A. (2001). Relationship of core self-evaluations to goal setting, motivation and

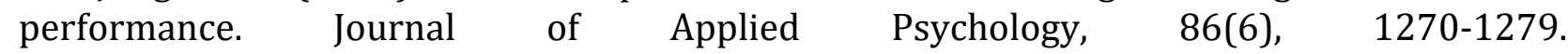
Https://Doi.Org/10.1037/0021-9010.86.6.1270

Festinger, L. (1954). A theory of social comparison processes. Human Relations, 7(2), 117- 140.

Fletcher, T. D., ve Nusbaum, D. N. (2010). Development of the competitive work environment scale: A multidimensional climate construct. educational and psychological measurement, 70(1), 105-124. Https://Doi.Org/10.1177/0013164409344492 
Fornell, C., ve Larcker, D. F. (1981). Evaluating structural equation models with unobservable variables and measurement error. Journal of Marketing Research, 18(1), 39-50. Jstor. Https://Doi.Org/10.2307/3151312

Foster, G. M. (1972). The anatomy of envy: A study in symbolic behavior. California Digital Library University of California, 39. Https://Doi.Org/10.1086/201267

Garcia, S. M., Tor, A., \& Schiff, T. M. (2013). The psychology of competition: A social comparison perspective. Perspectives on Psychological Science, 8(6), 634-650.

Geurts, S., Schaufeli, W., ve De Jonge, J. (1998). Burnout and intention to leave among mental healthcare professionals: A social psychological approach. Journal of Social and Clinical Psychology, 17(3), 341-362. Https://Doi.Org/10.1521/Jscp.1998.17.3.341

Gibbons, F.X. ve Buunk, B.P. (1999). Individual differences in social comparison: The development of a scale of social comparison orientation. Journal of Personality and Social Psycholog., 76, 129142

Ghadi, M. Y. (2018). Empirical examination of theoretical model of workplace envy: Evidences from jordan. Management Research Review, 41(12), 1438-1459. Https://Doi.Org/10.1108/Mrr06-2017-0185

Gino, F., ve Pierce, L. (2009). Dishonesty in the name of equity. Psychological Science, 20(9), 11531160. Https://Doi.Org/10.1111/J.1467-9280.2009.02421.X

Goette, L., Huffman, D., Meier, S., ve Sutter, M. (2012). Competition between organizational groups: Its impact on altruistic and antisocial motivations. Management Science, 58(5), 948-960. Https://Doi.Org/10.1287/Mnsc.1110.1466

Goukasian, L., ve Wan, X. (2010). Optimal incentive contracts under relative income concerns. Mathematics and Financial Economics, 4(1), 57-86. Https://Doi.Org/10.1007/S11579-0100035-9

Guerrero, L. K., Andersen, P. A., Jorgensen, P. F., Spitzberg, B. H., ve Eloy, S. V. (1995). Coping with the green-eyed monster: Conceptualizing and measuring communicative responses to romantic jealousy. Western Journal of Communication, 59(4), 270-304. Https://Doi.Org/10.1080/10570319509374523

Gurel Atay, E., Xie, G. X., Chen, J., ve Kahle, L. R. (2010). Changes in social values in the united states: 1976-2007: "Self-respect" is on the upswing as "a sense of belonging" becomes less important. Journal of Advertising Research, 50(1),57-67.https://Doi.Org/10.2501/S002184991009118x

Günalan, M. (2019). Olumsuz bir duygu olarak iş yerinde kıskançlık ve örgüt algıları ilişkisi üzerine bir literatür incelemesi. The Journal of Social Sciences, 43(43), 323-335. Https://Doi.Org/10.29228/Sobider.39758

Güney, S., Akalın, Ç., ve İlsev, A. (2007). Duygusal örgütsel bağlılık gelişiminde algılanan örgütsel destek ve örgüt temelli öz-saygı. Hacettepe Üniversitesi İktisadi ve İdari Bilimler Fakültesi Dergisi, 25(2), 189-211. Https://Dergipark.Org.Tr/Tr/Pub/Huniibf/103449

Harman, H. H. (1960). Modern factor analysis. Univ. Of Chicago Press.

Henseler, J., Ringle, C. M., ve Sarstedt, M. (2015). A new criterion for assessing discriminant validity in variance-based structural equation modeling. Journal of The Academy of Marketing Science, 43(1), 115-135. Https://Doi.Org/10.1007/S11747-014-0403-8 
Hu, L., ve Bentler, P. M. (1999). Cutoff criteria for fit indexes in covariance structure analysis: Conventional criteria versus new alternatives. Structural Equation Modeling: A Multidisciplinary Journal, 6(1), 1-55. Https://Doi.Org/10.1080/10705519909540118

Iacobucci, D., Saldanha, N., ve Deng, X. (2007). A meditation on mediation: Evidence that structural equations models perform better than regressions. Journal of Consumer Psychology, 17(2), 139-153. Https://Doi.Org/10.1016/S1057-7408(07)70020-7

Ingram, P., ve Qingyuan Yue, L. (2008). Structure, affect and identity as bases of organizational competition and cooperation. Academy of Management Annalis, 2(1), 275-303. Https://Doi.Org/10.5465/19416520802211578

Isaksen, K., ve Roper, S. (2016). Brand ownership as a central component of adolescent self-esteem: The development of a new self-esteem scale. Psychology ve Marketing, 33(8), 646-663. Https://Doi.Org/10.1002/Mar.20906

Jacob, D., ve Neuhäuser, C. (2018). Workplace democracy, market competition and republican selfrespect. Ethical Theory and Moral Practice, 21(4), 927-944. Https://Doi.Org/10.1007/S10677-018-9935-1

Johnson, C. (2012). Behavioral responses to threatening social comparisons: From dastardly deeds to rising above. Social and Personality Psychology Compass, 6(7), 515-524

Johnson, P. D., ve Swab, R. G. (2018). Steel sharpens steel: A review of multilevel competition and competitiveness in organizations. Journal of Organizational Behavior, 40(2), 147-165 https://doi.org/10.1002/job.2340

Kampen, T., Elshout, J., ve Tonkens, E. (2013). The fragility of self-respect: emotional labour of workfare volunteering. Social Policy and Society, 12(3), 427-438. Https://Doi.Org/10.1017/S1474746413000067

Kapıcı, S., ve Radmard, S. (2019). Eğitim örgütlerinde çatışma ve çatışma yönetimi üzerine bir araştırma: İzmir balçova örneği. İstanbul Aydın Üniversitesi Eğitim Fakültesi Dergisi, 2(2), 5579. Https://Dergipark.Org.Tr/En/Pub/İauefd/587551

Karaçam, A., Pulur, A., ve Adigüzel, N. S. (2017). Beden eğitimi öğretmenlerinin mesleki haz ve fiziksel öz saygı düzeyleri arasındaki ilişkinin incelenmesi. Beden Eğitimi ve Spor Bilimleri Dergisi, 11(3), 278-287. Https://Dergipark.Org.Tr/Tr/Pub/Bsd/711676

Keçecioğlu, T., ve Yılmaz, M. K. (2018). İşe adanmışlık: Mevcut düşüncenin gözden geçirilmesi. Business Economics and Management Research Journal, 1(1), 55-71.

Khon, A. (1992). No contest: The case against competition. Boston Newyork: Houghton Mifflin Company.

Kıral, E. (2018). Kıskançlık ölçeğinin Türkiye örnekleminde psikolojik özellikleri: Öğretmenlerde bir uygulama., 9. Uluslararası Eğitim Yönetimi Forumu Bildiri Özetleri Kitabı, Antalya, Türkiye, 14 Kasim 2018

Kıral, E., ve Ödemiş Keleş, N. (2019). Öğretim elemanlarının kıskançlığa ilişkin algıları. Eğitim Araştırmaları. Ankara: Eğitim Yöneticileri ve Uzmanları Derneği Yayınları.

Kline, R. B. (2016). Principles and practice of structural equation modeling (Fourth Edition). Newyork: The Guilford Press.

Korman, A. K. (1966). Self-esteem variable in vocational choice. Journal of Applied Psychology, 50(6), 479-486. Https://Doi.Org/10.1037/H0024039 
Krueger, J., Suls, J. ve Wheeler L., (2000). The projective perception of the social world. Handbook of Social Comparison (Ss. 323-351). Springer Us. Https://Doi.Org/10.1007/978-1-4615-42377_16

Kumashiro, M., Finkel, E. J., ve Rusbult, C. E. (2002). Self-respect and pro-relationship behavior in marital relationships: Self-respect in marital relationships. Journal of Personality, 70(6), 1009-1050. Https://Doi.Org/10.1111/1467-6494.05030

Landkammer, F., ve Sassenberg, K. (2016). Competing while cooperating with the same others: The consequences of conflicting demands in co-opetition. Journal of Experimental Psychology: General, 145(12), 1670-1686. Https://Doi.Org/10.1037/Xge0000232

Lange, J., ve Crusius, J. (2015). Dispositional envy revisited: Unraveling the motivational dynamics of benign and malicious envy. Personality and Social Psychology Bulletin, 41(2), 284-294. Https://Doi.Org/10.1177/0146167214564959

Le Fevre, M., Matheny, J., ve Kolt, G. S. (2003). Eustress, distress and interpretation in occupational $\begin{array}{lllll}\text { stress. Journal of } & \text { Managerial }\end{array}$ Https://Doi.Org/10.1108/02683940310502412

Luft, J. (2016). Cooperation and competition among employees: Experimental evidence on the role of management control systems. Management Accounting Research, 31, 75-85. Https://Doi.Org/10.1016/J.Mar.2016.02.006

Mael, F., ve Ashforth, B. E. (1992). Alumni and their alma mater: a partial test of the reformulated model of organizational identification. Journal of Organizational Behavior, 13(2), 103-123. Https://Doi.Org/10.1002/Job.4030130202

Malkoç, A., ve Erginsoy, D. (2012). Rekabetçi tutum, bilişsel çarpıtmalar ve çok boyutlu kıskançlık. Psikoloji Çalışmaları, 28, 1-14. Https://Dergipark.Org.Tr/Tr/Pub/İupcd/117911

Mardia, K. V. (1970). Measures of multivariate skewness and kurtosis with applications. Biometrika, 57(3), 519-530. Https://Doi.Org/10.1093/Biomet/57.3.519

Massey, S. J. (1983). Is self-respect a moral or a psychological concept? Ethics, 93(2), 246-261. Https://Doi.Org/10.1086/292432

Mckinnon, C. (2003). Basic income, self-respect and reciprocity: Basic income, self-respect and reciprocity. Journal of Applied Philosophy, 20(2), 143-158. Https://Doi.Org/10.1111/14685930.00243

Melwani, S., ve Barsade, S. G. (2011). Held in contempt: The psychological, interpersonal and performance consequences of contempt in a work context. Journal of Personality and Social Psychology, 101(3), 503-520. Https://Doi.Org/10.1037/A0023492

Muthén, L. K., ve Muthén, B. O. (2017). Mplus statistical analysis with latent variables user's guide (Eighth Edition). Los Angeles: Muthén ve Muthén.

Neff, K. D. (2003). The development and validation of a scale to measure self-compassion. Self and Identity, 2(3), 223-250. Https://Doi.Org/10.1080/15298860309027

Noy, C. (2008). Sampling knowledge: The hermeneutics of snowball sampling in qualitative research. International Journal of Social Research Methodology, 11(4), 327-344. Https://Doi.Org/10.1080/13645570701401305

Özen, S. (2007). İşyerinde psikolojik şiddet ve nedenleri. The Journal of Industrial Relations and Human Resources, 9(3), 1-24. Https://Doi.Org/10.4026/1303-2860.2007.0047.X 
Özer, Z. (2002). Kıskançlık. Bilim ve Teknik E-Dergisi, 413, 72-75.

Özdemir, S. (2018). Akademik örgütlerde kıskançlık üzerine fenomenolojik bir çalışma, Doktora Tezi, Isparta, 2018

Parks, C. D., Rumble, A. C., ve Posey, D. C. (2002). The effects of envy on reciprocation in a social dilemma. Personality and Social Psychology Bulletin, 28, 509-520. Https://Doi.Org/10.1177/0146167202287008

Parrott, W. G., ve Smith, R. H. (1993). Distinguishing the experiences of envy and jealousy. Journal of Personality and Social Psychology, 64(6), 906-920. Https://Doi.Org/10.1037/00223514.64.6.906

Penny, R. (2013). Incentives, inequality and self-respect. Res Publica, 19(4), 335-351. Https://Doi.Org/10.1007/S11158-013-9225-7

Pierce, J. L., ve Gardner, D. G. (2004). Self-esteem within the work and organizational context: A review of the organization-based self-esteem literature. Journal of Management, 30(5), 591622. Https://Doi.Org/10.1016/J.Jm.2003.10.001

Pierce, J. L., Gardner, D. G., Dunham, R. B., ve Cummings, L. L. (1993). Moderation by organizationbased self-esteem of role condition-employee response relationships. Academy of Management Journal, 36(2), 271-288. Https://Doi.Org/10.2307/256523

Pines, A., ve Aronson, E. (1983). Antecedents, Correlates and consequences of sexual jealousy. Journal of Personality, 51(1), 108-136. Https://Doi.Org/10.1111/J.1467-6494.1983.Tb00857.X

Podsakoff, P. M., Mackenzie, S. B., Lee, J.-Y., ve Podsakoff, N. P. (2003). Common method biases in behavioral research: A critical review of the literature and recommended remedies. Journal of Applied Psychology, 88(5), 879-903. Https://Doi.Org/10.1037/0021-9010.88.5.879

Poortvliet, P. M. (2013). Harming others' task-related efforts: The distinct competitive effects of ranking information on performance and mastery goal individuals. Social Psychology, 44(6), 373-379.

Raykov, T., ve Marcoulides, G. A. (2008). An introduction to applied multivariate analysis. New York: Routledge. Https://Doi.Org/10.4324/9780203809532

Renger, D. (2017). Believing in one's equal rights: Self-respect as a predictor of assertiveness. Self and Identity, 17(1), 1-21. Https://Doi.Org/10.1080/15298868.2017.1313307

Renger, D., Eschert, S., Teichgräber, M. L., ve Renger, S. (2019). Internalized equality and protest against injustice: The role of disadvantaged group members' self-respect in collective action tendencies. European Journal of Social Psychology, 50(3), 547-560. Https://Doi.Org/10.1002/Ejsp.2637

Roland, C. E., ve Foxx, R. M. (2003). Self-respect: A neglected concept. Philosophical Psychology, 16(2), 247-288. Https://Doi.Org/10.1080/09515080307764

Sachs, D. (1981). How to distinguish self-respect from self-esteem. Philosophy ve Public Affairs, 10(4), 346-360. Http://Www.Jstor.Org/Stable/2265048

Salovey, P., ve Rodin, J. (1988). Coping with envy and jealousy. Journal of Social and Clinical Psychology, 7(1), 15-33. Https://Doi.Org/10.1521/Jscp.1988.7.1.15 
Salvador, A., ve Costa, R. (2009). Coping with competition: Neuroendocrine responses and cognitive variables. Neuroscience \& Biobehavioral Reviews, 33(2), 160-170. Https://Doi.Org/10.1016/J.Neubiorev.2008.09.005

Seçkin, Ş. N. (2020). Algılanan rekabetçi iş ortamı ve nicel iş güvencesizliğinin işe bağlı gerginliğe $\begin{array}{lllll}\text { etkisi. Yönetim } & \text { Bilimleri }\end{array}$ Https://Doi.Org/10.35408/Comuybd.582756

Silvera, D. H., Lavack, A. M., ve Kropp, F. (2008). Impulse buying: The role of affect, social influence, and subjective wellbeing. Journal of Consumer Marketing, 25(1), 23-33. Https://Doi.Org/10.1108/07363760810845381

Simpson, C. K., ve Boyle, D. (1975). Esteem construct generality and academic performance. Educational and Psychological Measurement, 35(4), 897-904. Https://Doi.Org/10.1177/001316447503500416

Smith, R. (2008). Envy in organizational life. Oxford University Press. Https://Doi.Org/10.1093/Acprof:Oso/9780195327953.001.0001

Smith, R. D. (2000). Self-respecti. Arizona: Bell \& Howell Information and Learning Company.

Sorensen, J. (1999). The ecology of organizational demography: Managerial tenure distributions and organizational competition. Industrial and Corporate Change, 8(4), 713-744. Https://Doi.Org/10.1093/İcc/8.4.713

Stanne, M. B., Johnson, D. W., ve Johnson, R. T. (1999). Does competition enhance or inhibit motor performance: A meta-analysis. Psychological Bulletin, 1(125), 133-154.

Statman, D. (2000). Humiliation, dignity and self-respect. Philosophical Psychology, 13(4), 523-540. Https://Doi.Org/10.1080/09515080020007643

Steinfield, C., Ellison, N. B., ve Lampe, C. (2008). Social capital, self-esteem and use of online social network sites: A longitudinal analysis. Journal of Applied Developmental Psychology, 29(6), 434-445. Https://Doi.Org/10.1016/J.Appdev.2008.07.002

Stepan-Norris, J., ve Southworth, C. (2010). Rival unionism and membership growth in the united states, 1900 to 2005: A special case of inter-organizational competition. American Sociological Review, 75(2), 227-251. Https://Doi.Org/10.1177/0003122410365308

Swab, R. G., ve Johnson, P. D. (2019). Steel sharpens steel: A review of multilevel competition and competitiveness in organizations. Journal of Organizational Behavior, 40(2), 147-165. Https://Doi.Org/10.1002/Job.2340

Taylor, S.E., Peplau, L.A. ve Sears, D.O. (2007). Sosyal psikoloji (Çev., A. Dönmez), Ankara: İmge.

Tai, K., Narayanan, J., ve Mcallister, D. J. (2012). Envy as pain: Rethinking the nature of envy and its implications for employees and organizations. Academy of Management Review, 37(1), 107129. Https://Doi.Org/10.5465/Amr.2009.0484

Tarhan, N. (2018). Duyguların Ppsikolojisi. İstanbul: Timaş Yayınları.

Taştan, S., ve Aydın Küçük, B. (2019). Üretkenliğe aykırı çalışma davranışlarını açıklayan psikososyal yapılar olarak işyerinde kıskançlık duygusu ve strese yönelik esnekliğin incelenmesi. Süleyman Demirel Üniversitesi İktisadi ve İdari Bilimler Fakültesi Dergisi, 24(1), 55-79. Https://Dergipark.Org.Tr/Tr/Pub/Sduiibfd/703288 
Telfer, E. (2010). Self-respect and the respect of others. European Journal of Philosophy, 18(1), 1740. Https://Doi.Org/10.1111/J.1468-0378.2008.00332.X

Thompson, G., Glasø, L., ve Martinsen, Ø. (2016). Antecedents and consequences of envy. The Journal of Social Psychology, 156(2), 139-153. Https://Doi.Org/10.1080/00224545.2015.1047439

Töremen, F., ve Çankaya, İ. (2008). An effective approach at management: Emotional management. Kuramsal Eğitimbilim $\quad$ Dergisi, $\quad 1(1), \quad 33-47$. Https://Dergipark.Org.Tr/Tr/Pub/Akukeg/313942

Truong, Y., ve Mccoll, R. (2011). Intrinsic motivations, self-esteem and luxury goods consumption. Journal of Retailing and Consumer Services, 18(6), 555-561. Https://Doi.Org/10.1016/J.Jretconser.2011.08.004

Üçok, D. (2019). Çalışanlardaki statü endişesi ve işbirliğine dayalı amaç yapılarının işyeri kıskançlığı üzerindeki etkilerine ilişkin kuramsal bir çalışma. International Journal of Management and Administration. 3(5), 1-12. Https://Doi.Org/10.29064/İjma.484933

Van De Ven, N., Zeelenberg, M., ve Pieters, R. (2009). Leveling up and down: The experiences of benign and malicious envy. Emotion, 9(3), 419-429. Https://Doi.Org/10.1037/A0015669

Van De Voorde, K., Paauwe, J., ve Van Veldhoven, M. (2012). Employee well-being and the hrmorganizational performance relationship: A review of quantitative studies. International Journal Of Management Reviews, 14(4), 391-407. Https://Doi.Org/10.1111/J.14682370.2011.00322.X

Van Houten, R. (1979). Social validation: The evolution of standards of competency for target behaviors. Journal of Applied Behavior Analysis, 12 (4), 581-591.

Vecchio, R. P. (2000). Negative emotion in the workplace: Employee jealousy and envy. International Journal Of Stress Management, 7(3), 161-179.

Wang, Y.D., ve Sung, W.C. (2016). Predictors of organizational citizenship behavior: Ethical leadership and workplace jealousy. Journal of Business Ethics, 135(1), 117-128. Https://Doi.Org/10.1007/S10551-014-2480-5

Wittchen, M., Krimmel, A., Kohler, M., ve Hertel, G. (2013). The two sides of competition: Competitioninduced effort and affect during intergroup versus interindividual competition. British Journal Of Psychology, 104(3), 320-338. Https://Doi.Org/10.1111/J.2044-8295.2012.02123.X

Yeşilada, T., ve Yeniçeri, İ. (2020). Banka çalışanları arasında yaşanan rekabet algısı ile iş etiği algısının etkileşimi. Dokuz Eylül Üniversitesi İşletme Fakültesi Dergisi, 21(1), 161-175. Https://Doi.Org/10.24889/İfede.459246

Yıldırım, F. B., ve Demir, A. (2017). Kendini engellemenin yordayıcıları olarak öz saygı, öz anlayış ve akademik öz yeterlilik. Ege Eğitim Dergisi, 18(2), 676-701. Https://Doi.Org/10.12984/Egeefd.315727

Yücel, R., ve Solak, B. (2012). The effects of accountant professionals' social responsibility perceptions on self esteem and job performance. Atatürk Üniversitesi İktisadi ve İdari Bilimler Dergisi, 26(3-4), 15-31. Https://Dergipark.Org.Tr/Tr/Pub/Atauniiibd/35718

Yüner, Berna. (2018). Örgüt temelli öz saygı ile duygusal örgütsel bağlılığa ilişkin öğretmen görüşleri. Ankara Üniversitesi Eğitim Bilimleri Fakültesi Özel Eğitim Dergisi. 19(4), 777-799 Https://Doi.Org/10.21565/Ozelegitimdergisi.396246 
Zurriaga, R., González-Navarro, P., Buunk, A. P., ve Dijkstra, P. (2018). Jealousy at work: The role of rivals' characteristics. Scandinavian Journal of Psychology, 59(4), 443-450. Https://Doi.Org/10.1111/Sjop.12443 


\section{EXTENDED ABSTRACT}

\section{The Role of Self-Esteem in the Effect of Intra-Organizational Competition on Organizational Jealousy: A Study on Civil Aviation Employees}

\section{Introduction}

Studies on how competition between individuals or groups affect organizations or employees are relatively few (Johnson \& Swab, 2018). Some of these studies concluded that a competitive work environment enables employees behave competitively individually or as a group (Fletcher \& Nusbaum, 2010) and increases organizational performance (Brown, Cron, \& Slocum, 1998), and concluded that the relationship between job performance and job satisfaction is strengthened (Arnold \& Flaherty, 2010). Despite their accepted existence in work environments, employee jealousy is also a neglected issue in organizational sciences (Vecchio, 2000). According to the results of related studies, jealousy; negatively affecting group performance and group cohesion, leading to social loafing, withdrawal or leaving the company (Dogan \& Vecchio, 2001), less collaborative behaviour (Parks, Rumble \& Posey, 2002) and less effort by employees. As a result of expenditures, it causes a decrease in the value of the firm (Goukasian and Wan, 2010). According to the results of the study on self-esteem; it has been determined that self-esteem increases workplace satisfaction (Pierce et al., 1993), organizational commitment (Güney, Akalın, \& İlsev, 2007) and job performance (Yücel \& Solak, 2012). In the results of the study on competition and jealousy, it was concluded that the intra-organizational competitive environment can create feelings similar to jealousy (Dogan \& Vecchio, 2001), while uncontrolled jealousy brings with it destructive competition (Eginli \& Bitirim, 2010).

\section{Data Set and Method}

The main population of the research consists of the employees of Turkish aviation companies that also have international operations. The number of employees in the universe of the research is unknown and sampling was made because it was not possible to reach all of the employees. The sample consists of aviation employees working at an intense and tiring pace under time pressure. The main purpose in this selection is the idea that the intense competition among the companies in the sector can cause competition among the employees as well. In addition, since the sector includes the human element in the success of many operations, it is a sector where human relations are important. For this reason, it is predicted that competition among employees may also trigger jealousy.

Snowball sampling method was used as the sampling method. Accordingly, after the first research group or individuals are found, the researcher reaches new participants through these individuals (Noy, 2008). The reason for the preference of this method is that it is aimed to reach the employees directly related to the subject. Thus, employees who are in direct competition or who are exposed to jealousy (or jealous of others) have been reached.

The questionnaire form, which was prepared in the electronic platform, was sent to 50 employees who were contacted at the first stage. Among these employees, those who were related to the subject answered the questionnaire directly, and those who thought that it was not related to the subject forwarded the questionnaire to their related friends in the electronic platform as well. Thus, we reached 256 employees. 59.84\% of the participants were female $(n=152)$ and $40.16 \%$ were male $(n$ = 102). While the working time of the participants, all of whom work in air services, is 4.9 years at their current workplace, the average tenure in the sector is 6.8 years. Structural Equation Modeling (SEM) was adopted in the analysis of the data obtained by the survey method. 


\section{Empirical Findings}

According to the findings of the study, it has been observed that intra-organizational competition increases the envy of others and the thinking that they are jealousy and decreases the self-esteem. It has been concluded that self-esteem reduces envy and mediates the relationship between competition and jealousy within the organization.

\section{Discussion and Conclusion}

Finding of the study is in parallel with the research of Ghadi (2018). Competition and competitive environment, which is always seen as positive, actually creates a ground for jealousy within the organization. As a matter of fact, Stanne et al. (1999) argue that working in cooperation rather than intra-organizational competition is more beneficial in this regard. Parks et al. (2002) also stated that jealous people are less cooperative. According to another finding of the study, it was concluded that intra-organizational competition reduces self-esteem. According to the results of previous studies in the literature (Bonham, 2013; Thompson et al., 2016), jealousy is a phenomenon that reduces selfesteem. In the research, it was concluded that self-esteem mediates the relationship between intraorganizational competition and envy and envy of others. In other words, individuals with high selfesteem do not envy others or think that they are envied, even if they are in a competitive environment. Self-esteem is the individual's having strong ideas about himself (Telfer, 2010) and seeing himself as equal to others in terms of his rights and dignity (Statman, 2000). For this reason, it is not expected that individuals with high self-esteem will behave like jealousy. The findings of the study also support these views. 